\title{
New Evidence of MIS 3 Relative Sea Level Changes from the Messina Strait, Calabria (Italy)
}

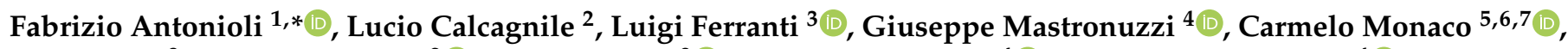 \\ Paolo Orrù ${ }^{8}$, Gianluca Quarta ${ }^{2}$ (D) Fabrizio Pepe ${ }^{9}$ (D), Giovanni Scardino ${ }^{4}$, Giovanni Scicchitano ${ }^{4}$, \\ Paolo Stocchi ${ }^{10}$ and Marco Taviani ${ }^{11,12,13}$
}

check for updates

Citation: Antonioli, F.; Calcagnile, L.; Ferranti, L.; Mastronuzzi, G.; Monaco,

C.; Orrù, P.; Quarta, G.; Pepe, F.;

Scardino, G.; Scicchitano, G.; et al.

New Evidence of MIS 3 Relative Sea Level Changes from the Messina Strait, Calabria (Italy). Water 2021, 13, 2647. https://doi.org/10.3390/ w13192647

Academic Editor: Gary B. Griggs

Received: 5 July 2021

Accepted: 21 September 2021

Published: 26 September 2021

Publisher's Note: MDPI stays neutral with regard to jurisdictional claims in published maps and institutional affiliations.

Copyright: (c) 2021 by the authors. Licensee MDPI, Basel, Switzerland. This article is an open access article distributed under the terms and conditions of the Creative Commons Attribution (CC BY) license (https:// creativecommons.org/licenses/by/ $4.0 /)$.
1 Istituto Nazionale di Geofisica e Vulcanologia (INGV), via di Vigna Murata, 00144 Rome, Italy

2 CEDAD, Department of Mathematics and Physics "Ennio de Giorgi", University of Salento, 73100 Lecce, Italy; lucio.Calcagnile@unisalento.it (L.C.); gianluca.quarta@unisalento.it (G.Q.)

3 Dipartimento di Scienze della Terra, dell'Ambiente e delle Risorse, Napoli University Federico II, 80126 Napoli, Italy; luigi.ferranti@unina.it

4 Dipartimento di Scienze della Terra e Geoambientali, Università degli Studi di Bari Aldo Moro, 70125 Bari, Italy; giuseppe.mastronuzzi@uniba.it (G.M.); giovanni.scardino@uniba.it (G.S.); giovanni.scicchitano@uniba.it (G.S.)

5 Dipartimento di Scienze Biologiche Geologiche e Ambientali, Catania University, 95129 Catania, Italy; cmonaco@unict.it

6 CRUST-Interuniversity Center for 3D Seismotectonics with Territorial Applications, 66100 Chieti Scalo, Italy 7 Istituto Nazionale di Geofisica e Vulcanologia, Osservatorio Etneo, 95131 Catania, Italy

8 Dipartimento di Scienze Chimiche e Geologiche, Cagliari University, 09042 Cagliari, Italy; orrup@unica.it

9 Dipartimento di Scienze della Terra e del Mare, Palermo University, 90123 Palermo, Italy; fabrizio.pepe@unipa.it

10 NIOZ Royal Netherlands Institute for Sea Research, Utrecht University, Landsdiep 4, 16797 SZ 't Horntje (Texel), The Netherlands; paolo.stocchi@nioz.nl

11 Institute of Marine Sciences (CNR-ISMAR) Bologna, 40129 Bologna, Italy; marco.taviani@cnr.it

12 Stazione Zoologica Anton Dohrn, 80122 Napoli, Italy

13 Biology Department, Woods Hole Oceanographic Institution, Woods Hole, MA 02543-1050, USA

* Correspondence: fabrizioantonioli2@gmail.com

Abstract: Investigation of sea-level positions during the highly-dynamic Marine Isotope Stage 3 (MIS 3: 29-61 kyrs BP) proves difficult because: (i) in stable and subsiding areas, coeval coastal sediments are currently submerged at depths of few to several tens of meters below the present sea level; (ii) in uplifting areas, the preservation of geomorphic features and sedimentary records is limited due to the erosion occurred during the Last Glacial Maximum (LGM) with sea level at a depth of $-130 \mathrm{~m}$, followed by marine transgression that determined the development of ravinement surfaces. This study discusses previous research in the Mediterranean and elsewhere, and describes new fossiliferous marine deposits overlaying the metamorphic bedrock at Cannitello (Calabria, Italy). Radiocarbon ages of marine shells (about 43 kyrs cal BP) indicate that these deposits, presently between 28 and $30 \mathrm{~m}$ above sea level, formed during MIS 3.1. Elevation correction of the Cannitello outcrops (considered in an intermediate-to-far-field position with respect to the ice sheet) with the local vertical tectonic rate and Glacial Isostatic Adjustment (GIA) rate allows the proposal of a revision of the eustatic depth for this highstand. Our results are consistent with recently proposed estimates based on a novel ice sheet modelling technique.

Keywords: Marine Isotope Stage 3; relative sea level; tectonics; GIA; Calabria

\section{Introduction \\ 1.1. MIS 3 Sea Level Historical Background}

Marine Isotope Stage 3 was a time of strong climatic contrasts, likely in response to changes in the Atlantic Meridional Overturning Circulation [1]. A precise assessment of sea level positions for this interstadial has proved to be elusive and controversial (lastly 
revised by Siddall et al. [2]). Indeed, estimates of the global sea-level during MIS 3 range between -15 and $-87 \mathrm{~m}$ [3-7]. One major problem concerns reconstructions based upon indirect proxies, like the widely used stable oxygen stratigraphy that translates into ice volumes (and related sea-level oscillations) and the geochemical signals incorporated into benthonic or planktonic foraminifera from core records $[3,8]$.

Oppositely, the advantage of using cores to investigate sea-level positions is represented by the continuity of their records. This contrasts the discontinuous record offered by Pleistocene coral reefs and uplifted or buried sedimentary sequences, which have, on the other hand, the advantage to provide direct physical evidence of former sea levels [2,9]. The highly diverse and variegated nature of available markers, coupled with intrinsic difficulties to precisely date deposits $>40 \mathrm{kyr}$, accounts in recognising MIS 3 as 'enigmatic' [2]. From a climatic perspective, MIS 3 is a crucial time interval since it was characterised by frequent (millennial) and abrupt thermal oscillations, that strongly reverberated in the variations of sea levels $[2,10,11]$.

It is, therefore, of paramount importance to estimate the sea level position during this interstadial. Most reconstructions on MIS 3 appear to exclude that the sea level ever reached depths greater than $-60 /-50 \mathrm{~m}[2,6,9,12-14]$. The aim of this paper was to discuss MIS 3 position extracted from marine deposits outcropping in Calabria (Italy, Figure 1), a strongly uplifting area of the central Mediterranean. We selected the Cannitello site in southern Calabria where uplift rates have been calculated using a flight of raised Pleistocene terraces that includes the last interglacial terraces [15].

\subsection{Regional Setting}

Calabria is the emerging part of a forearc terrane belonging to the Ionian subduction system. The subducting Ionian lithosphere dips $\sim 70-80^{\circ}$ northwestward down to a depth of 450-500 km (see inset in Figure 1; [16-19]). The upper plate of the subduction system, from west to east, consists of back-arc basins that become younger southeastward (Vavilov and Marsili basins; [20-22]), an arc-shaped volcanic ridge (i.e., Aeolian islands), and a forearc-accretionary wedge system including the Calabrian Arc (CA) [23,24].

The CA experienced vigorous uplift during the Quaternary [25,26]. Vertical movements cumulate the effects of both regional and local processes. The latter was related to footwall uplift along extensional faults [27-32]. Hanging-wall subsidence counteracts the effects of regional uplift, which, in the long-term, prevails [31,33]. The CA has been stretched by WNW-ESE oriented Quaternary extension [33-35]. Today, belts of active extensional faults run along the chain axis and the Tyrrhenian side of the northern and southern CA, respectively. 


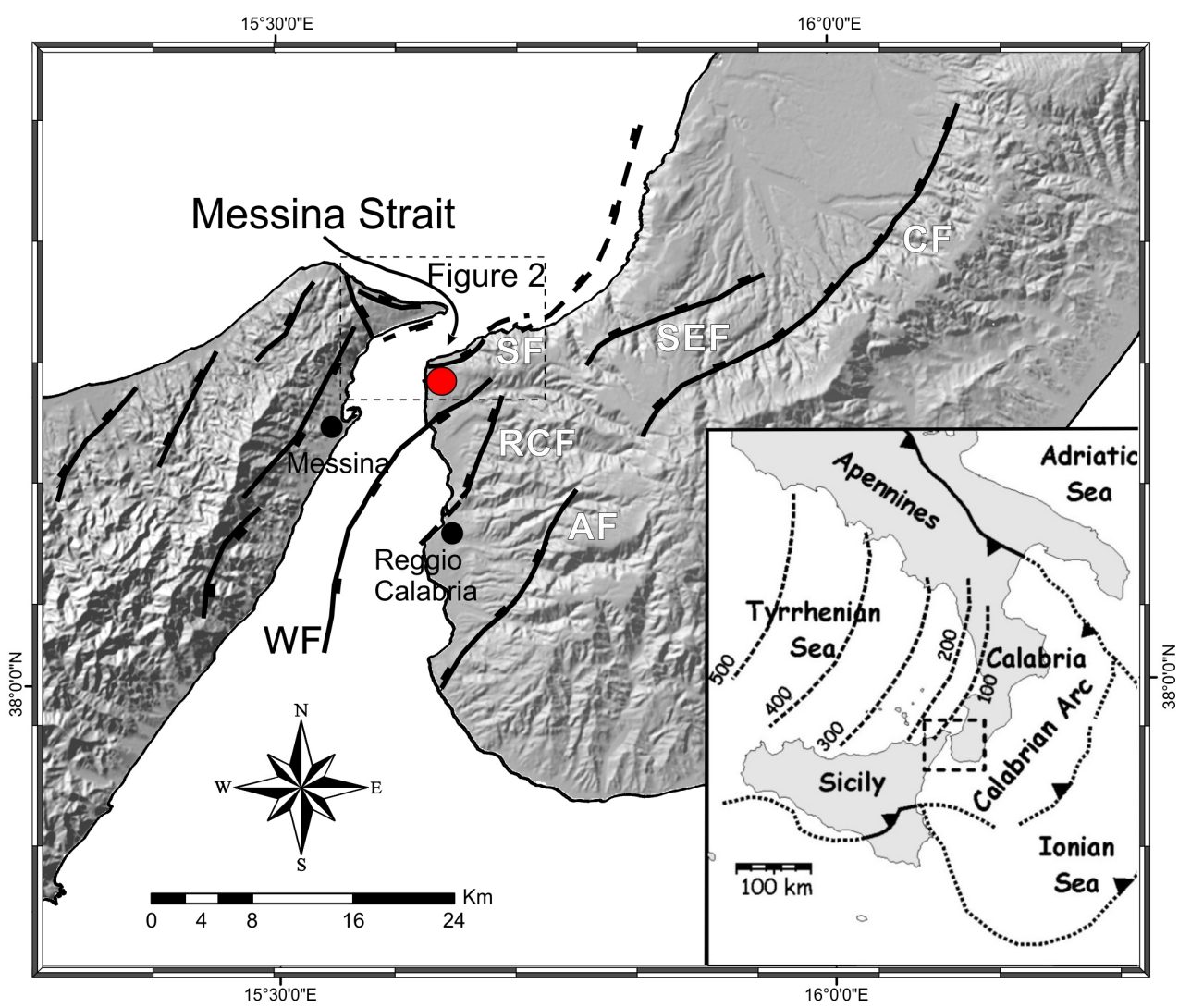

Figure 1. Tectonic setting of the Messina Strait region in the southern part of the Calabrian Arc. Active faults (thick solid lines barbed on the downthrown side) after Monaco and Tortorici [36] and Barreca et al. [37]: AF, Armo Fault; RCF, Reggio Calabria Fault; CF, Cittanova Fault; SEF, S. Eufemia Fault; SF, Scilla Fault, and W-Fault. The red balloon indicates the studied Cannitello site. The inset shows the location of the study area in the tectonic setting of the Central Mediterranean (from Chiarabba et al. [38]).

\subsection{Study Area}

The study area is located on the Calabrian side of the Strait of Messina (southern sector of the Calabrian Arc, Figure 1). The strait is a Pliocene-Quaternary basin limited by ENEWSW to NNE-SSW striking normal faults offsetting Palaeozoic metamorphic basement rocks and Miocene terrigenous covers [27,28,39,40] (Figure 1). The stratigraphic architecture of the basin consists of Lower Pliocene chalks, Upper Pliocene-Lower Pleistocene calcarenites, up to the middle Pleistocene Messina Gravels and Sands Fm [41-43].

These sequences are unconformably overlain by terraced Pleistocene marine deposits $[15,26,44-46]$, ranging in elevation from 40 to $1200 \mathrm{~m}$ a.s.l. The marine terraced series is partly displaced by the Scilla Fault and by the Cappuccini Fault, which bounds the Piale High $[27,28,33,47-49]$ to the north and south, respectively (Figure 2). The terraced deposits consist of fossiliferous calcarenites or sublittoral sands and sandy gravels, more or less cemented, directly lying on the Palaeozoic metamorphic basement or on the PliocenePleistocene deposits $[26,44,46]$. The marine deposits generally pass upwards to continental colluvial reddish silt with sands and gravels levels.

The lowest and youngest terrace extends along the coast, from Villa S. Giovanni to Cannitello area, where it seals the western end of the Scilla Fault, with an inner edge at $45 \mathrm{~m}$ a.s.l. Balescu et al. [50] correlated this terrace with the Isotope Stage 3 (60 ka, [51]) based on the Thermo Luminescence and Optically Stimulated Luminescence (OSL) ages of associated aeolian sands. This paleoshoreline corresponds to the lowest one mapped by Monaco et al. [15] (Figure 1) and attributed by the authors to the MIS 3.3. 


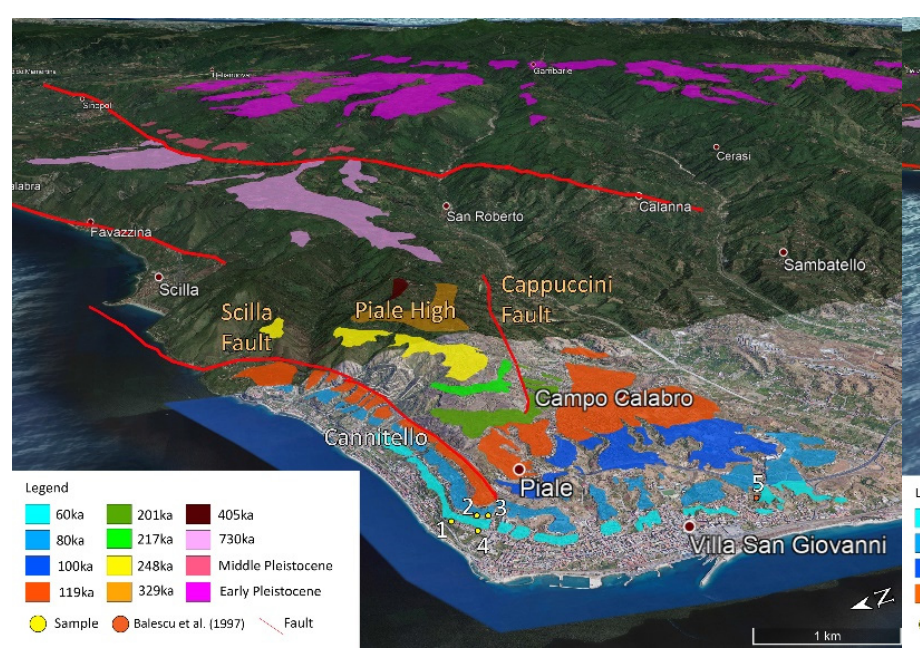

(a)

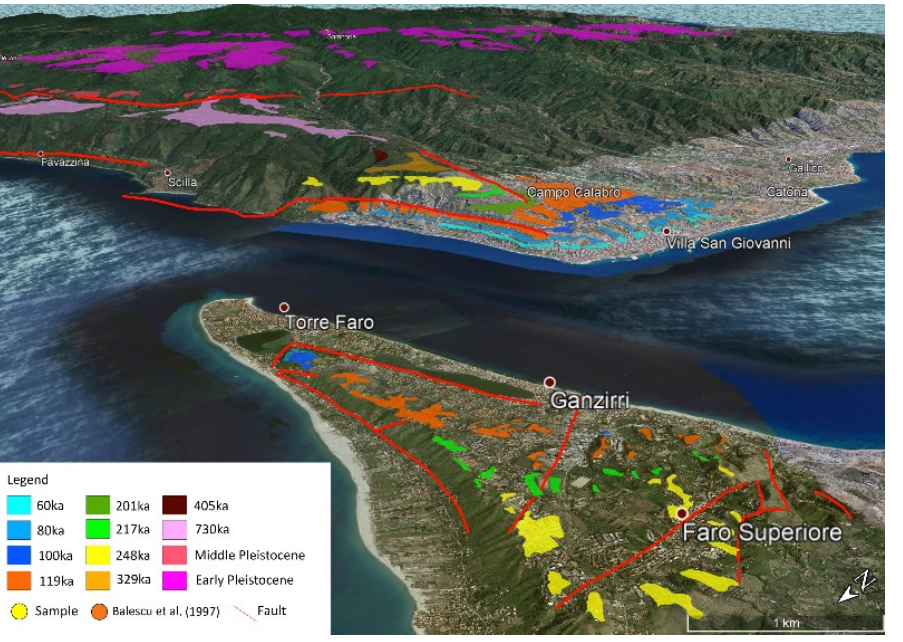

(b)

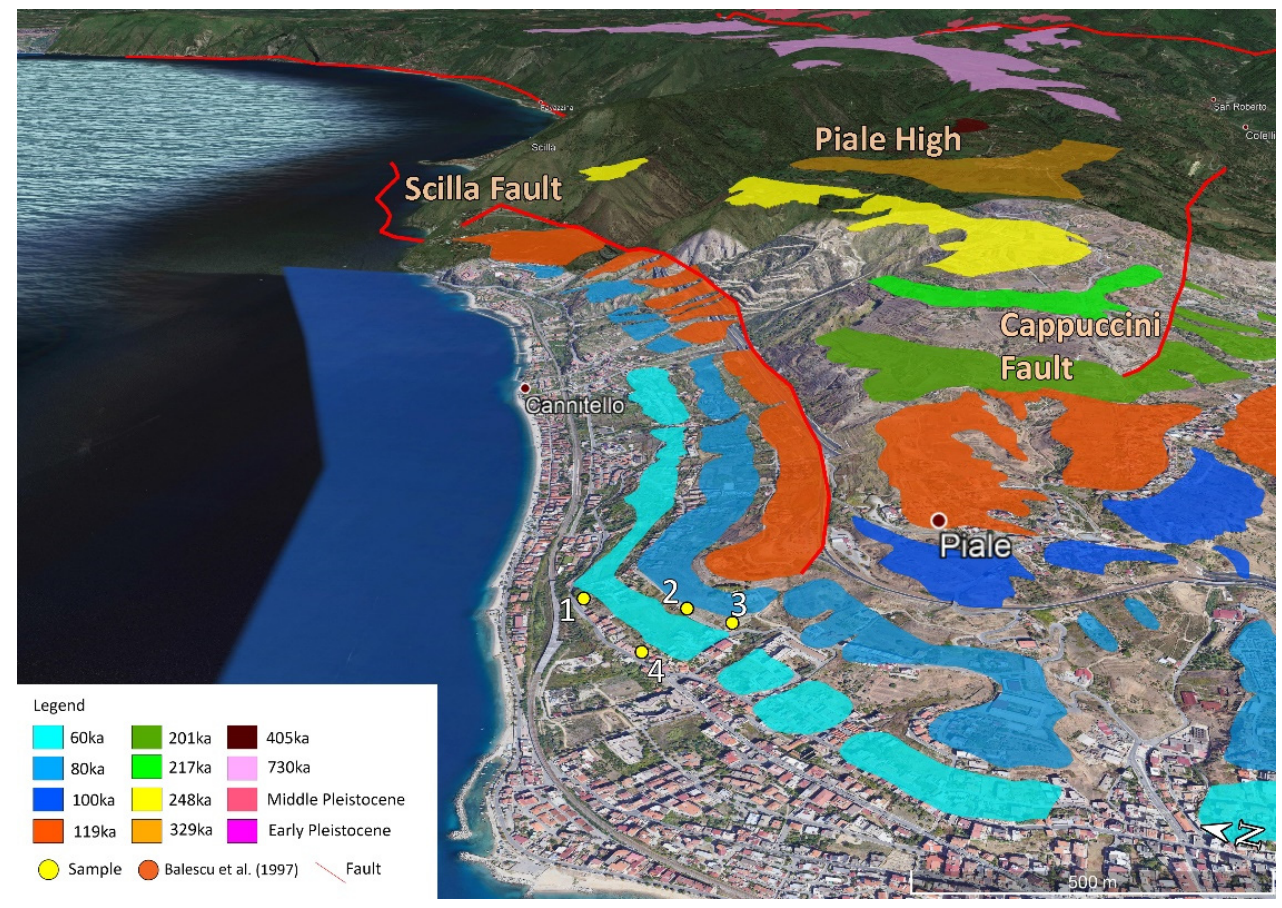

(c)

Figure 2. (a-c) Maps of the terraced sequence (see Figure 1 for location).

The upper terraces extend around the Piale High, extensively outcropping on the hanging wall of the Scilla Fault northward and along the south-west side with inner edges at elevations between 60-85 and $205 \mathrm{~m}$ a.s.l. The complete sequence outcrops only on the Piale High (Figure 2), where the oldest terraces show inner edges at elevations between 285 and $520 \mathrm{~m}$ a.s.l. These oldest terraces are represented by wave-cut platforms directly resting on the crystalline substratum and are covered by silts and reddish continental sands.

The absolute dating obtained by Balescu et al. [50], crossed with geomorphological correlations to deposits containing Thetystrombus latus (Gmelin, 1791) Persististrombus latus (Gmelin, 1791) Strombus bubonius (Lamarck, 1822) in the Reggio Calabria area [26,45,52,53] robustly constrain the age of the whole sequence, whose highest terrace has been attributed to the MIS 11 (405 kyrs, Figure 2). A more elevated terrace, associated with marine deposits containing Globorotalia truncatulinoides excelsa [54], reaches an elevation of $680 \mathrm{~m}$. It was attributed to the MIS 25 ( $950 \mathrm{ka}$ ) by Miyauchi et al. [26], but more likely must be referred to the MIS 19 ( 730 ka). A complete map of Quaternary coastal terraces, obtained from 
Miyauchi et al. [26], is shown in Figure 2 where, following the authors, the highest terraces are assigned to middle-lower Pleistocene.

\section{Previous Studies on MIS 3}

\subsection{MIS3 in the Global Context}

On a global scale, a limited number of studies have specifically considered MIS 3 RSL records [55]. For instance, deposits and paleoshorelines ascribed to MIS 3 have been found in Grand Bahamas where Richards et al. [56] found evidence that the MIS 3.3 highstand exceeded the depth of $-18.1 \mathrm{~m}$ as speleothem GB-89-25-5C shows a hiatus between 63.7 and 58.5 kyrs. However, the highstand does not exceed the $-15 \mathrm{~m}$ depth of flowstone DWBAH [57,58] (Figure 3). The Bahamas flowstone DWBAH may prove to represent a sea-level marker of utmost global importance, since encompassing a continuous record from 326 up to $37 \mathrm{kyrs}$ BP, with five hiatuses corresponding to many marine highstands. The comparison of DWBAH altitude data with the speleothem of Richards et al. [56], not presenting hiatus for MIS $3(-18.1 \mathrm{~m})$, sets an upper limit $(-16 \mathrm{~m})$ for the MIS 3.3 highstand.

\section{Bahamas}

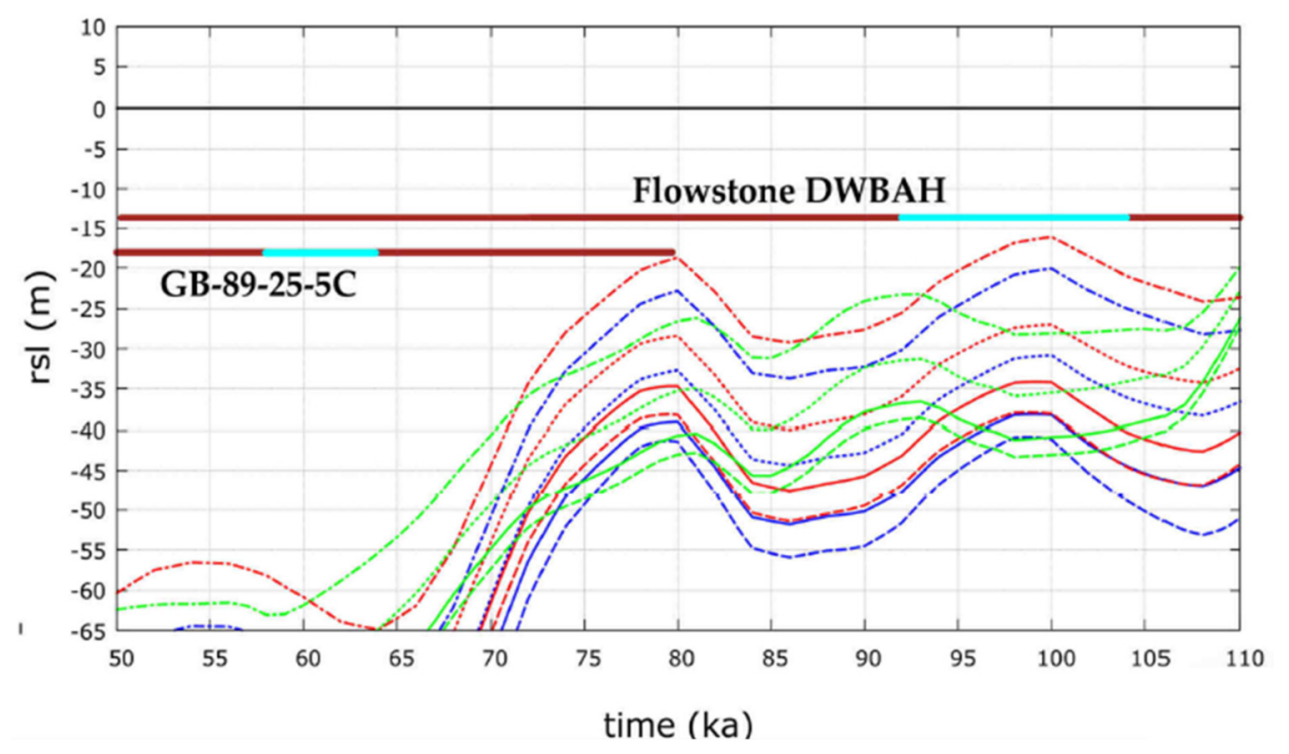

Figure 3. Constraints on MIS 3 depth from the Bahamas. The submerged speleothem GB-(89) sampled in the Blue Hole (Bahamas) at -18.1 m [56] shows a hiatus between 63.7 and 58.5 kyrs. Glacial and hydro-isostatic Adjustments (GIA) at Bahamas is similar to that of the Central Mediterranean sea [59]. Predicted RSL curves for the ICE-5G (red curves), ICE-6G (green curves), and ANICE-SELEN (blue curves) ice sheet models in combination with MVP 1-3 mantle viscosity profiles (solid, dashed and dotted lines, respectively) at each site and with respect to the measured elevations.

Lambeck et al. [8] described a MIS 3 deposit at about $-50 /-60 \mathrm{~m}$ along the coasts of Bonaparte Gulf and Huon Peninsula. However, such results could be affected by an underestimation of the tectonic contribution. An integrated study of the Gulf of Mexico offshore using high-resolution seismics, extensive coring, and dating $\left({ }^{14} \mathrm{C}\right.$ AMS ages and stable isotope stratigraphy) supplies considerable evidence of a MIS 3 sea level high-stand. The shoreline (as a brackish lagoon proxy) likely reached up to $-15 /-18 \mathrm{~m}$ below the present sea level at ${ }^{14} \mathrm{C}$ ages of about 37-40 ky BP [4]. Evidence of circum-Antarctic emerged marine deposits attributed to MIS 3 was summarised by Berkman et al. [60]. Wide shelfal sectors in the Weddell and Ross seas were probably under open-water conditions at this time $[61,62]$.

Pico et al. [63] refined estimates of the global ice volume during MIS 3 by employing sediment cores in the Bohai and Yellow Sea, that recorded the migration of the paleo- 
shoreline at 50-37 ka through a transition from marine to brackish conditions, defining a peak global mean sea level of $38 \pm 7 \mathrm{~m}$ during the interval 50-37 ka.

\subsection{A Mediterranean MIS3 Perspective}

In the Mediterranean region, sea-level information for the MIS 3 mainly relates to offshore cores ([64-67]) and on combinations of offshore and onland boreholes [68-76]. These data chiefly report the position of continental or marine deposits ascribed to MIS 3 within marginal sequences; however, their value to assess the sea level positions with confidence is rather limited. Additional reference to MIS 3 is found in other records, including submerged terraces [77] and prehistoric contexts [78].

Regarding the eastern Mediterranean, Dogan et al. [79] focused their attention on fossilferous units cropping along the Samandag coast, Turkey. They applied the electron spin resonance (ESR) method to molluscs to identify MIS 5.1 and MIS 3 deposits. The study estimated for the area a fast uplift that is likely related to the vertical component of the strike-slip active faults in the Samandag Antakya Fault Zone. Data analysis and vertical tectonic movements suggested a $-40 \mathrm{~m}$ eustatic position of MIS 3 in this coastal area of Turkey. Kirci-Elmas et al. [67], based upon floro-faunal arguments, proposed that the Izmit Gulf was connected with the Black Sea and the Mediterranean Sea at the beginning of MIS-3 (ca. 52.0-40.0 ky BP).

A borehole drilled by 'Regione Emilia-Romagna' in the Po Plain (Italy) onshore the Adriatic coast encountered, at about $30 \mathrm{~m}$ below the surface, sandy layers interpreted as representing a fluviatile facies [68]. Noticeably, fresh shells of the marine intertidal gastropod Nassarius circumcinctus (A. Adams, 1852) picked from these sands were ${ }^{14} \mathrm{C}$ dated at ca. $37 \mathrm{kyr}$ (A. Viesce, pers. com.). Thus, the sandy layer might represent a former marine shoreline, currently located about $30 \mathrm{~m}$ below the surface and ascribable to MIS 3 [78]. This evidence merits further investigation because it may shed new light on sea level variations during MIS 3.

On the other side of the north Adriatic Sea, in Lošinj (Croatia), Brunović et al. [80] attributed a deposit found at about $-50 \mathrm{~m}$, in a brackish-to freshwater lacustrine body, to MIS 3. Antonioli et al. [59], in a review paper on the use of submerged speleothems in the Mediterranean Sea, provided sea level information about MIS 3 for several areas of the Mediterranean basin. Along the Croatian side of the northern Adriatic Sea, speleothems collected inside submerged caves proved that MIS 3 never exceeded a $-18.8 \mathrm{~m}$ depth (after correction for subsidence affecting the coastal area [81]).

Along the Tyrrhenian sea coastline, submerged stalagmites collected in the Argentarola Island showed an uninterrupted continental deposition during MIS 3, testifying that the sea level did not reach values shallower than $-21.7 \mathrm{~m}[82,83]$. Along the Ionian coast of south-eastern Sicily, Dutton et al. [84] analysed several stalagmites found inside caves developed along paleo shorelines presently submerged at about -20 and $-40 \mathrm{~m}$ [85]. Samples collected along the deepest paleo shorelines showed a continuous growth of continental layers inside the speleothems during MIS 3, proving that the sea level has never been shallower than $-38 \mathrm{~m}$ (using a tectonic uplift rate of $0.2 \mathrm{~mm} / \mathrm{y}$ ).

Along the Ionian Sea coast of northern Calabria, a flight of eleven terraces dated to the Middle-Late Pleistocene indicates uplift at $\sim 1 \mathrm{~mm} / \mathrm{yrs}$ [86-88]. The lowermost terrace (T1), with an inner edge at an elevation between 11-24 and $17 \mathrm{~m}$ at the foot of the Pollino and Sila mountain ranges, respectively, was attributed to MIS 3.1 by Ferranti et al. [86] based on a ${ }^{14} \mathrm{C}$ calibrated age of $44 \pm 0.4 \mathrm{ka}$ from a 'Cardium' shell sampled at the Pollino range coast. The sample was taken from a conglomerate deposit in the bank of a stream cutting terrace T1; however, although resedimented in the recent alluvial system, it likely comes from terrace T1, and thus the existence of MIS 3 was ascertained.

Based on borehole data, Santoro et al. [87] documented a 10-15 $\mathrm{m}$ thickness of T1 coarse marine-transitional deposits and suggested that it includes both MIS 3.3 and 3.1, as the terrace was sea-flooded during the two peaks of the MIS 3. Santoro et al. [85] indicated, at the Pollino coast, the existence of a lower terrace (T0) with an inner edge at 5-11 (average 
$8 \mathrm{~m}$ ) and suggested that T1 (average $15 \mathrm{~m}$ ) formed during MIS 3.3. This attribution would support that the age from the 'Cardium' shell refers to terrace T0 that is, thus, attributed to MIS 3.1.

With an uplift rate of $0.9 \mathrm{~mm} / \mathrm{y}$ established by Santoro et al. [88] on the MIS 5.5 terrace (dated by Ferranti et al. [86]), a 43 ka old terrace with an inner margin presently at $+8 \mathrm{~m}$ should have been uplifted of $38 \mathrm{~m}$; thus, it formed at $-30 \mathrm{~m}$ below the present sea-level. Further north, raised marine deposits that have been attributed to MIS 3 by means of OSL age determinations have been recognized along the Ionian coast of Basilicata $[89,90]$.

\section{The Cannitello Site}

\subsection{Geological-Paleontological Description}

Several outcrops of fossiliferous sublittoral deposits are found in the Cannitello location. The sites were positioned through GPS RTK, and orthometric heights were obtained using the IGM (Italian Geographic Military Institute) grids for the Calabria area.

The most relevant site (Cannitello 1, elevation $28 \mathrm{~m}$; Figure 2, Table 1) is stratigraphically located beneath the outer margin of the terrace attributed to MIS 3.3 [15]. The $3 \mathrm{~m}$ thick stratigraphic section (Figure $4 \mathrm{a}$ ) presents fine sands at the base, with flat parallel lamination in a marly silty matrix with fine gravel levels (1). This deposit is engraved by a surface of sub-planar erosion on medium sands in silty matrix in plane-parallel position (2) characterised at the base by a level of heterometric pebbles (2a) with a thickness of $10 \mathrm{~cm}$. A Mitylus shell (Sample 1, Table 2) was sampled from one of the levels containing fragments of bivalves and gastropods (Figure 4a).

Table 1. The Cannitello studied sites altitudes; see also Figure 2.

\begin{tabular}{ccccc}
\hline Site Number & Latitude & Longitude & GPS Altitude m & $\begin{array}{c}\text { Google Earth } \\
\text { Altitude m }\end{array}$ \\
\hline CANNITELLO 1 & $38.232280 \mathrm{~N}$ & $15.644851 \mathrm{E}$ & 28.382 & 30 \\
\hline CANNITELLO 2 & $38.230440 \mathrm{~N}$ & $15.644630 \mathrm{E}$ & 57.201 & 57 \\
\hline CANNITELLO 3 & $38.229399 \mathrm{~N}$ & $15.643769 \mathrm{E}$ & 48.122 & 47 \\
\hline CANNITELLO 4 & $38.230805 \mathrm{~N}$ & $15.642728 \mathrm{E}$ & 27.282 & 28 \\
\hline
\end{tabular}

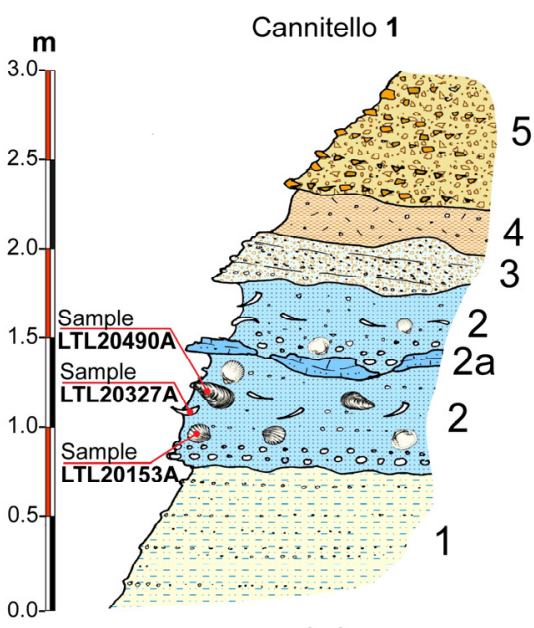

(a)

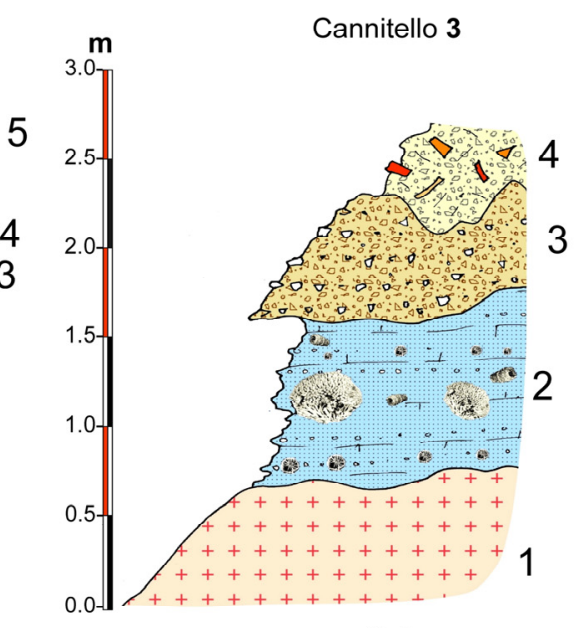

(b)

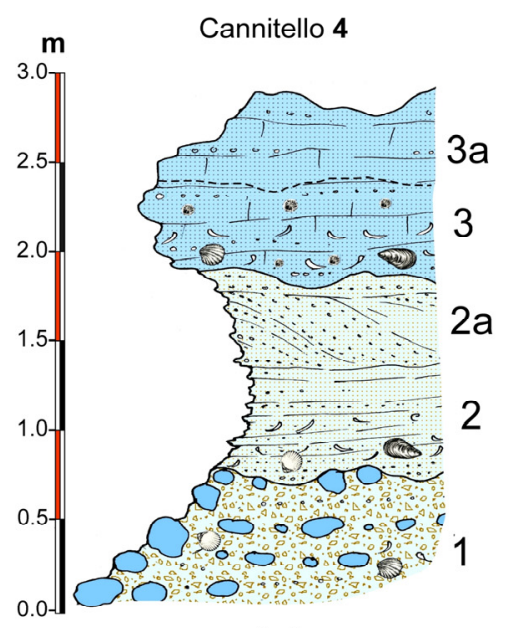

(c)

Figure 4. (a-c) Stratigraphic sections of the sites Cannitello 1, 3, and 4. For Cannitello 1, we have highlighted the position of the sampled and dated fossils of Table 2 . 
Table 2. Radiocarbon ages: samples at Cannitello 1 site; see also Figures 5 and 6.

\begin{tabular}{cccccc}
\hline Sample & $\begin{array}{c}\text { Radiocarbon } \\
\text { Age Years (BP) }\end{array}$ & $\begin{array}{c}\text { Age Years Cal } \\
\text { BP 1sigma }\end{array}$ & $\boldsymbol{\delta}^{\mathbf{1 3}} \mathbf{C} \mathbf{( \% )}$ & Fossil & $\begin{array}{c}\text { Altitude } \\
\text { Satellite m }\end{array}$ \\
\hline LTL20153A & $>48,000$ & & $2.5 \pm 0.2$ & Mytilus & $28.3 \pm 0.2$ \\
\hline LTL20327A & $40,887 \pm 320$ & $43,152 \pm 304$ & $4.2 \pm 0.4$ & Gastropod & $28.3 \pm 0.2$ \\
\hline LTL20490A & $40,828 \pm 300$ & $43,092 \pm 273$ & $0.3 \pm 0.2$ & Arca noae & $29.3 \pm 0.2$ \\
\hline
\end{tabular}

In the top part of this level, the plane-parallel lamination resumes, and levels of lamellibranch fragments are observed. Medium sands with inclined lamination follow upward above an erosion surface proximal submerged beach environment foreset (3). The section is sealed at the top by continental deposits represented by a colluvial level (4) and a stratified slope deposit with poorly elaborated subangular pebbles (5).

The basal sedimentary level (2) of the Cannitello 3 site rests upon an irregular erosion surface carved within the altered metamorphic bedrock (1). Marine sediments likely documenting the mesolittoral and infralittoral environment are represented by fine sands and gravels with flat parallel lamination. This level is characterized by a weakly-cemented skeletal bryzoan hash dominated by Miriapora truncata (Pallas, 1766) biosomes. These marine deposits are overlaid by continental scree deposits containing aligned sub-angular pebbles (3), which are, in turn, blanketed by anthropic fill materials (4).

The site Cannitello 4 exposes a densely-packed shelly rudstone with abundant but degraded biosomes and bioclasts pertaining to infra-mesolittoral organisms, such as bivalves, e.g., Arca cf noe Linnaeus, 1758, cf. Acanthocardia tuberculata (Linnaeus, 1758), gastropods as Jujubinus cf striatus (Linnaeus, 1758), Alvania sp., naticid, Tritia sp., and scaphopods (Antalis sp.). Finally, a level of broken Mytilus shells was found. Although a precise bathymetric assessment based upon fossils is problematic; nonetheless, an estimated paleodepth between $10-30 \mathrm{~m}$ is not unreasonable (Figures 2 and $4-6$ ).

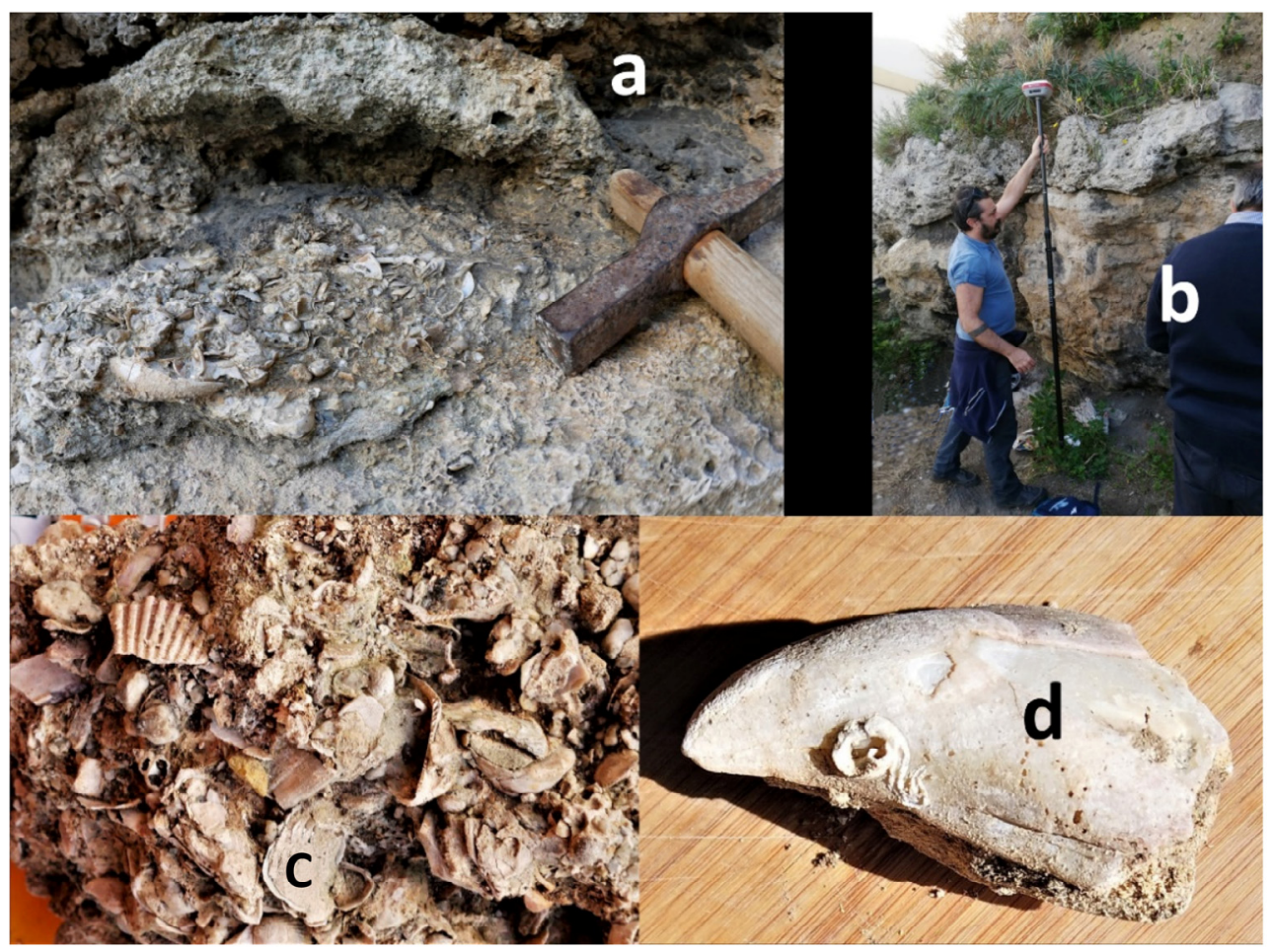

Figure 5. The Cannitello 4 and 1 outcrops. (a-c) The size and some details of the section. (d) A particular of Mytilus of Cannitello 1. 


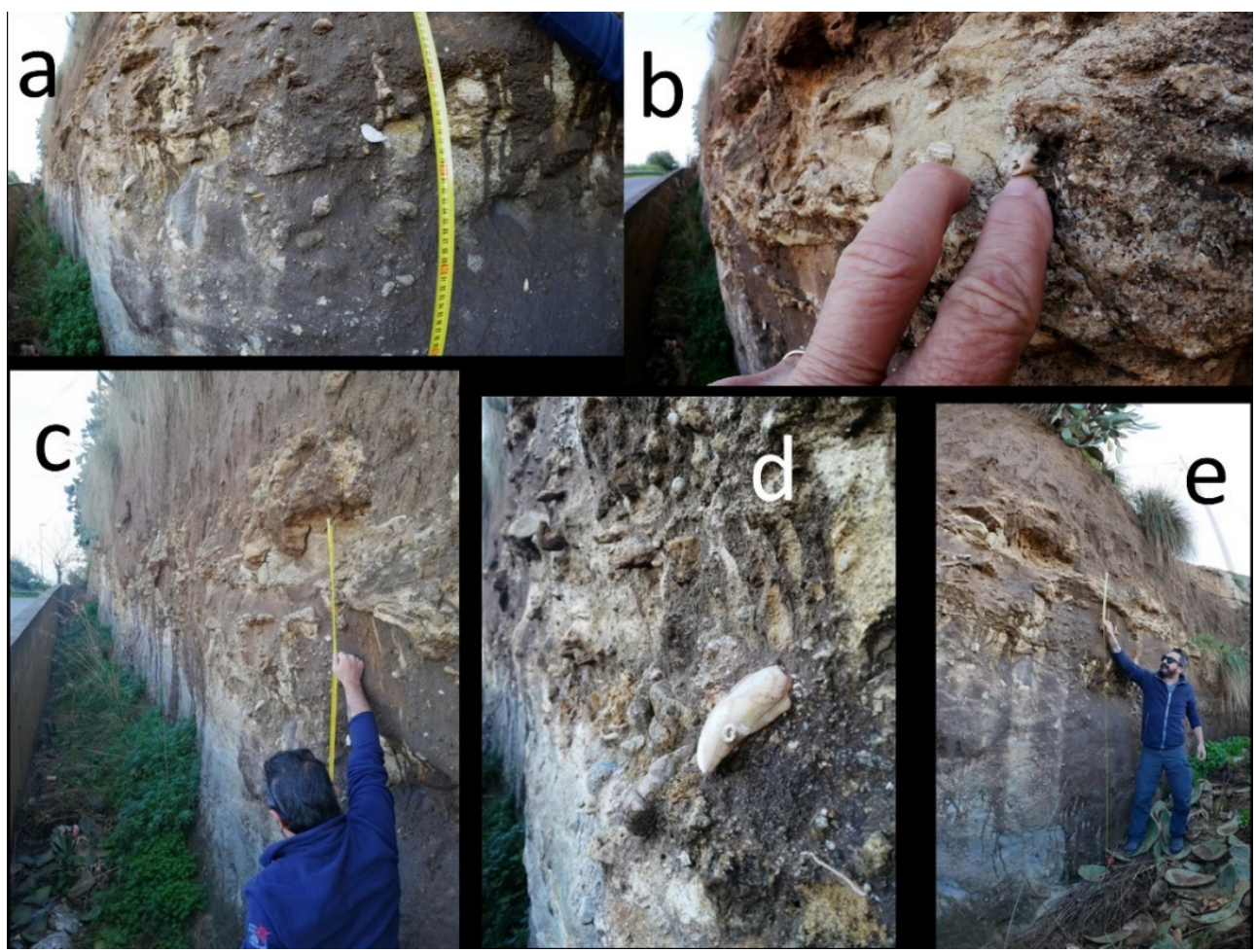

Figure 6. The Cannitello 1 outcrop. (a-c,e) The size and some details of the section. (d) The radiocarbon aged (sample LTL20153A of Table 2) Mytilus in situ.

In addition to these sites attributable to MIS3 (see below), we identified older Pleistocene marine deposits. For example, the site named Cannitello 2 ( $57.2 \mathrm{~m}$ elevation), located above the terrace attributed to MIS 3.3 [15], consists of well-cemented calcarenite encasing deep-water scleractinian corals, i.e., Desmophyllum dianthus (Esper, 1794), D. pertusum (Linnaeus, 1758), and Caryophyllia sp. In all likeness, these facies represent a Late to Middle Pleistocene bathyal deposit plastering a former submarine cliff, a common case in this region subjected to important uplift [91].

\subsection{Sampling and Radiocarbon Analyses}

Dated samples come from silt-sandy deposits at Cannitello 1 site and were easily extracted from the poorly cemented matrix. Radiocarbon dating analyses were carried out at CEDAD-Centre for Applied Physics, Dating and Diagnostics, Department of Mathematics and Physics, University of Salento in Lecce-Italy [92]. The samples were first analysed at the optical microscope in order to highlight possible macro-contamination such as the adhering residues of soils. They were then etched with $\mathrm{H}_{2} \mathrm{O}_{2}$ to remove the external layer and rinsed with de-ionized water.

The purified sample was then hydrolysed under a vacuum using $\mathrm{H}_{3} \mathrm{PO}_{4}$. The released $\mathrm{CO}_{2}$ was then cryogenically purified and then converted to graphite by using $\mathrm{H}_{2}$ as a reducing agent at $600{ }^{\circ} \mathrm{C}$ on Fe powder acting as a catalyst. For all three samples, $\sim 1 \mathrm{mg}$ of graphite was obtained, which is considered optimal for the following isotopic analyses. The obtained graphite was then used to measure the ${ }^{14} \mathrm{C} /{ }^{12} \mathrm{C}$ and ${ }^{13} \mathrm{C} /{ }^{12} \mathrm{C}$ isotopic ratio at the AMS (Accelerator Mass Spectrometry) beamline at CEDAD based on a $3 \mathrm{MV}$ Tandetron (Mod. HVEE 4130HC) accelerator.

The radiocarbon age of the samples was then calculated from the measured ${ }^{14} \mathrm{C} /{ }^{12} \mathrm{C}$ ratios by applying the radiocarbon decays law and after correcting the measured terms for mass fractionation and processing blanks. In particular, $\mathrm{C} 1$ carbonate standards (Carrara Marble completely depleted in ${ }^{14} \mathrm{C}$ supplied by IAEA (International Atomic Energy Agency, Vienna Austria) were used to estimate the machine and chemical processing blank during the whole process. Conventional radiocarbon ages were then calibrated in calendar years 
by using the last released calibration dataset for marine organisms (MARINE20) [93] and using a local marine reservoir correction term $\Delta \mathrm{R}=-88 \pm 50 \mathrm{y}$ as obtained by Siani et al. [94] and recalculated for the MARINE20 curve (Table 2).

Table 2 lists the radiocarbon dating results. Two samples fall within MIS 3.1, and one resulted out of the radiocarbon range $(>48,000$ years).

\section{GIA Modelling}

\subsection{Model Setting}

Existing estimations of MIS 3.1 and MIS3.3 RSL depths carry the contribution of both vertical land and mean sea surface (geoid) variations in response to the ice sheet fluctuations. Indeed, surface mass transfer from the oceans to the continents, and vice versa, in addition to altering the global ocean mass and volume (eustatic sea-level change), trigger solid Earth deformations and gravitational and rotational perturbations that affect the geoid.

This process is known as glacial- and hydro-isostatic adjustment (GIA) and causes local RSL changes to deviate from the global mean (eustatic) as a function of the distance from the ice sheets. Here, we account for the GIA process by solving the gravitationally self-consistent sea level equation (SLE) [56,57] and using the open-source program SELEN [58-60]. Accordingly, we compute the local RSL curves for prescribed solid Earth rheological models and ice sheet models.

We assumed a self-gravitating, rotating, spherically symmetric, radially stratified, deformable but not compressible Earth model. The latter is 1-dimensional, implying that all the relevant rheological parameters are a function of the Earth's radius only. The outer shell of the model is perfectly elastic and represents the lithosphere. Between the lithosphere and the inviscid core is the mantle, characterised by linear Maxwell viscoelastic rheology.

We employed a four-layer mantle discretisation where the upper mantle (UM), the lower upper mantle (LUM), the transition zone (TZ), and the lower mantle (LM) are characterised by uniform viscosity according to the VM2 profile (see Table 3). We combine this vertical stratification with a lithosphere thickness of $90 \mathrm{~km}$ and use it as a reference model. Furthermore, we consider three mantle viscosity profiles (MVPs) that are characterised by an increase in the vertical viscosity gradient from MVP1 to MVP3 (see Table 4). We use these three profiles in combination with a $100 \mathrm{~km}$ thick Lithosphere.

Table 3. Parameters of the four-layer mantle discretization; Litosheric Thickness (LT), Upper Mantle (UM), Lower Upper Mantle (LUM), Transition zone (TZ), and Lower Mantle (LM).

\begin{tabular}{cccccc}
\hline VM2 & LT $\mathbf{( k m )}$ & $\begin{array}{c}\text { UM } \\
\left(\times \mathbf{1 0}^{\mathbf{2 1}} \mathbf{P a} \cdot \mathbf{s}\right)\end{array}$ & $\begin{array}{c}\text { LUM } \\
\left(\times \mathbf{1 0}^{\mathbf{2 1}} \mathbf{P a} \cdot \mathbf{s}\right)\end{array}$ & $\begin{array}{c}\text { TZ } \\
\left(\times \mathbf{1 0}^{\mathbf{2 1}} \mathbf{P a} \cdot \mathbf{s}\right)\end{array}$ & $\begin{array}{c}\text { LM } \\
\left(\times \mathbf{1 0}^{\mathbf{2 1}} \mathbf{P a} \cdot \mathbf{s}\right)\end{array}$ \\
\hline 90 & 0.67 & 0.44 & 0.46 & 2.53 \\
\hline
\end{tabular}

Table 4. Vertical viscosity gradient increasing on the three mantle viscosity profiles (MVPs).

\begin{tabular}{ccccc}
\hline MVPs & LT $\mathbf{( k m})$ & $\mathbf{U M ~}\left(\times \mathbf{1 0}^{\mathbf{2 1}} \mathbf{P a} \cdot \mathbf{s}\right)$ & $\mathbf{T Z}\left(\times \mathbf{1 0}^{\mathbf{2 1}} \mathbf{P a} \cdot \mathbf{s}\right)$ & $\mathbf{L M}\left(\times \mathbf{1 0}^{\mathbf{2 1}} \mathbf{P a} \cdot \mathbf{s}\right)$ \\
\hline MVP1 & 100 & 1 & 1 & 2 \\
\hline MVP2 & 100 & 0.5 & 0.5 & 5 \\
\hline MVP3 & 100 & 0.25 & 0.5 & 10 \\
\hline
\end{tabular}

We employed four ice sheet model chronologies that can be divided into two categories:

1. $\delta_{-}{ }^{18} \mathrm{O}$-dependent ice sheet models:

1.1 ICE-5G and ICE-6G [95-98]: These global models describe the ice sheet thickness variations over North America, Eurasia, Greenland, and Antarctica for the last $123 \mathrm{ka}$. The 
ice thickness chronology between $26 \mathrm{ka}$ and the present day is constrained by geological and modern geodetical observations through an iterative procedure that involves the solution of the SLE for an a priori ice sheet configuration and a prescribed fixed solid Earth model (mantle viscosity profile and Lithosphere thickness). The ice sheet volumetric evolution between 123 and 26 ka was tuned to the delta- $18 \mathrm{O}$ curve [97] and, where possible, constrained by geological evidences that define the ice sheet coverage and margins.

1.2 ANICE-SELEN $[99,100]$ : This global chronology model is the result of an inverse forward modelling procedure where the delta- $18 \mathrm{O}$ stack [97] is decoupled into global ice sheet volume and deep-water temperature. For this purpose, 3D thermomechanical ice sheet models for North America, Eurasia, Greenland, and Antarctica, are dynamically coupled to SELEN in order to include all the GIA feedbacks. ANICE-SELEN is not constrained by geological or instrumental data.

2. $\delta-{ }^{18} \mathrm{O}$-independent ice sheet models:

2.1 PaleoMIST 1.0 [101]: This model stems from the combination of simplified 2dimensional ice flow modelling and geological data that constrain the ice sheet boundaries in space and time (2500 years temporal snapshots). The reconstructed ice sheet margins, once combined with the topography, allow for the calculation of the basal sheet stress that, for a prescribed ice flow law, yield the 2-dimensional, steady state ice thickness variations within the ice sheet margins.

The model is then improved by an iterative procedure where the SLE is solved to account for realistic changes in topography. RSl curves are computed for each iterative step and compared to dated near-field RSL observations (RSL database). The iterative process is run until convergence is found. Accordingly, the ice sheet model is independent of the far-field and global sea-level proxies that are based on deep sea $\delta-{ }^{18} \mathrm{O}$ records. We employ two versions of PaleoMIST 1.0: (i) Minimal MIS 3 and (ii) Maximal MIS 3, respectively, with and without major retreat of the Laurentide Ice Sheet.

Therefore, the eustatic sea-level curves of ICE-5G, ICE-6G, and ANICE-SELEN, which reflect the ice sheet volume variation in time and expressed in meters of equivalent sea level, strongly depend on the benthic oxygen curve. The eustatic curve of PaleoMIST 1.0, instead, depends on the areal extent of the ice sheets, which is constrained by surface geological indicators and is completely independent of the benthic oxygen curve.

We employ the reference VM2 profile (Table 3) combined with the four ice sheet models, while the three MVPs (Table 4) are only used for ICE-5G, ICE-6G, and ANICESELEN.

\subsection{Numerical GIA Predictions}

Numerical RSL predictions for the three ice sheet models that depend on the delta$18 \mathrm{O}$ record are very close to the corresponding eustatic curves, which represent the ice sheet volume variation in time expressed as meters of equivalent sea level (Figure 7). The expected GIA variability, i.e., the vertical difference of the GIA-modulated RSL curves with respect to the eustatic, is $\sim 2.5 \mathrm{~m}$ for ICE-5G (red curves in Figure 7) and ICE-6G (blue curves in Figure 7) and $~ 5.0-10.0 \mathrm{~m}$ for the ANICE-SELEN model runs (green curves in Figure 7). This confirms previous findings of Antonioli et al. [59,102] and stresses the major role of glacio-eustasy in this area and during the MIS 3 period.

Data model comparison reveals that the predicted MIS 3.1 and MIS 3.3 RSL elevations for ICE-5G, ICE-6G, and ANICE-SELEN were significantly lower than the observed values (corrected for tectonics). The GIA variability cannot explain the differences of 35-60 m and 30-50 m, respectively, at the MIS 3.1 and 3.3. 


\section{MIS 3 RSL at Cannitello}

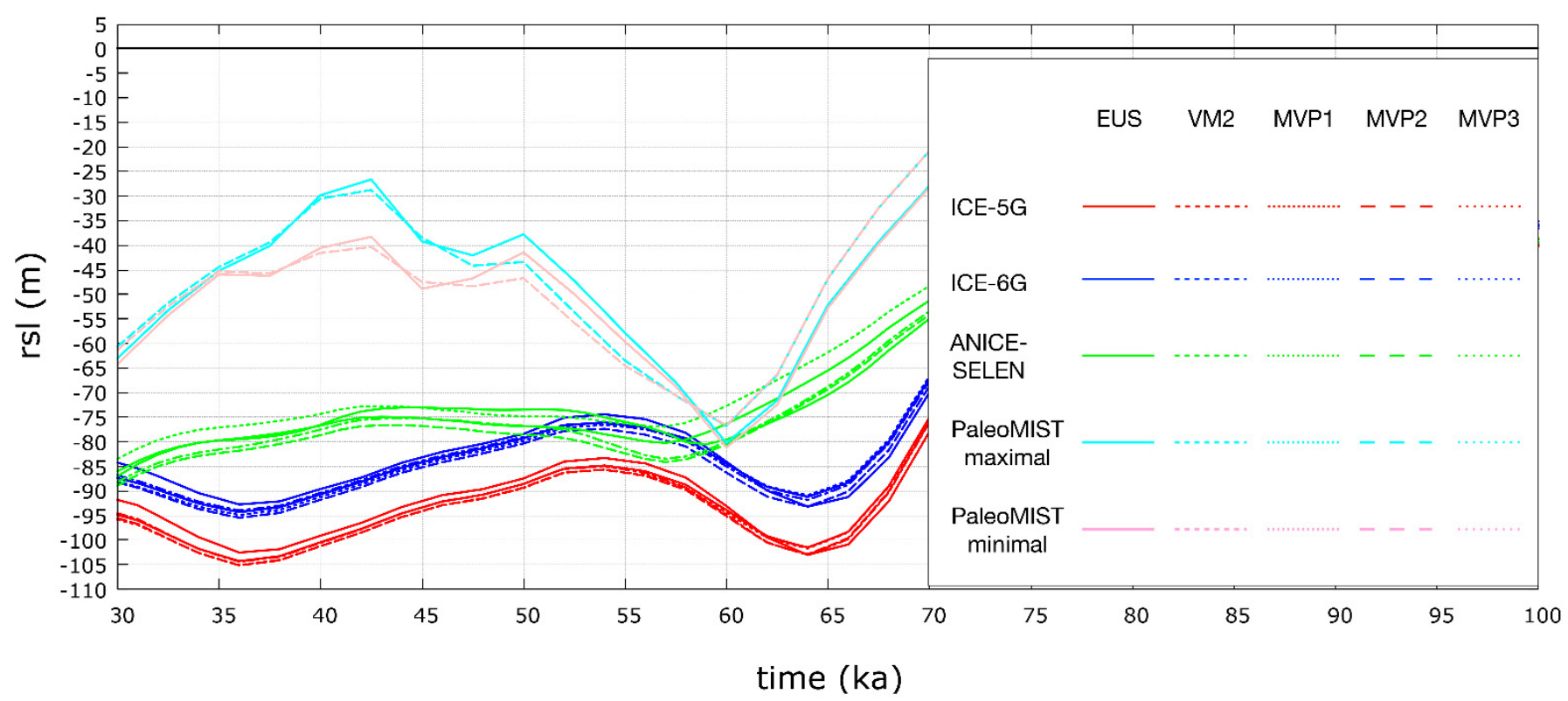

Figure 7. Predicted RSL curves for four ice sheet models: ICE-5G (red), ICE-6G (blue), ANICE-SELEN (cyan), and PaleoMIST 1.0 maximal and minimal (cyan and pink, respectively). The solid curves represent the eustatic. The dashed and dashed-dotted curves represent the GIA-modulated RSl predictions.

The predicted RSL curves for PaleoMIST 1.0 Maximal and Minimal MIS 3 (cyan and pink curves in Figure 7), both in combination with VM2 mantle profile (Table 3), were significantly above the ICE-5G, ICE-6G, and ANICE-SELEN curves (Figure 7). This implies that the PaleoMIST 1.0 ice sheet model was characterised by smaller ice volumes during the time frame under consideration.

Interestingly, the PaleoMISt 1.0 curves converge towards a minimum at $60 \mathrm{ka}$, which is broadly in line with the other models, where the minimum is slightly shifted at $\sim 65 \mathrm{ka}$. Accordingly, the predicted RSL elevation at the MIS 3.3 is $\sim 30 \mathrm{~m}$ lower than the tectonicallycorrected MIS 3.3 terrace at Cannitello. However, after $60 \mathrm{ka}$, the predictions for PaleoMIST 1.0 diverge and maximum highstands of -30 and $-40 \mathrm{~m}$ are obtained at $42.5 \mathrm{ka}$ for, respectively, the Minimal and Maximal MIS 3 versions. These values are in agreement with the tectonically-corrected MIS 3.1 elevation at Cannitello (and at the Ionian sea coast).

\section{Discussion}

The published global information coupled with new field data from southern Calabria suggests that the quantity of melted ice during MIS 3 could have been underestimated in the global curves [5,6]. In general, observed sea-level markers are largely consistent showing a sea level between -18 and $-40 \mathrm{~m}$, with a $30-40 \mathrm{~m}$ difference with respect to the global curves. An agreement exists between the predicted sea-level and observed markers with Gowan et al. [101] for MIS 5.3, 5.1, and 3.1.

The radiocarbon ages (Table 1) of samples collected at $28 \mathrm{~m}$ attribute Cannitello 1 stratigraphic section at MIS 3.1. The result is consistent with the age of the overlying marine terraces (see Table 5, in particular with the MIS 3.3 terrace at 45 metres (64 kyrs [50])).

The sedimentary features of the studied deposits suggest that they formed at the foot of a cliff in a high-energy environment (slope almost overlooking the sea with a relief that reaches 5-600 m). Today, the sea-bottom rapidly deepens respectively to -50 and $-100 \mathrm{~m}$ at 120 and $230 \mathrm{~m}$ offshore Cannitello. For these reasons, it is quite difficult to determine with great precision the depth of the foot of the paleocliff on which fossils sampled and aged at Cannitello 1 accumulated. 
Table 5. (1) Elevation of sea level markers from: this paper ${ }^{1}$; Monaco et al. [15] ${ }^{2}$; and Miyauchi et al. [26] ${ }^{3}$. The distinct inner edges were mapped by these authors with an error margin in the elevation of $\pm 5 \mathrm{~m}$, depending on the erosion and depositional processes following the emergence of the terraces. An error between 0 and $-10 \mathrm{~m}$ was applied for the fossil raised deposits *. This implies that the elevations above sea level of the inner edges must be considered as mean values. (2) The Marine Isotopic Stage attribution based on dating and geomorphological correlations (see text for explanations). (3) Age from: this paper ${ }^{1}$; Balescu et al. [50] ${ }^{2}$; Miyauchi et al. [26] and Monaco et al. [15] ${ }^{3}$; Antonioli et al. [103] ${ }^{4}$ and Senegalese fauna; Dutton et al. [83] ${ }^{5}$; and Lisieki and Raymo [97] ${ }^{6}$. (4) The eustatic sea level from: Gowan et al. [101]; this paper ${ }^{1}$; Waelbroek et al. [5] ${ }^{2}$; Dutton et al. [83] ${ }^{3}$; and Lisieki and Raymo [97] ${ }^{4}$. (5) The uplift rate calculated for each stage and (6) as the average value for the middle-late Pleistocene.

\begin{tabular}{|c|c|c|c|c|c|}
\hline $\begin{array}{c}1 \text { Observed } \\
\text { Elevation of Terraces Inner Margins } \\
\text { or Fossils/Infra/Circalittoral Raised } \\
\text { Deposits }{ }^{*} \mathrm{~m}\end{array}$ & $\begin{array}{l}2 \text { Marine Isotopic } \\
\text { Stage (MIS) }\end{array}$ & $\begin{array}{l}3 \text { Age } \\
\text { (ka) }\end{array}$ & $\begin{array}{l}4 \text { Eustatic Sea } \\
\text { Level }(\mathrm{m})\end{array}$ & $\begin{array}{l}5 \text { Uplift Rate } \\
\mathrm{mm} \backslash y\end{array}$ & $\begin{array}{l}6 \text { Mean } \\
\text { Uplift Rate } \\
\text { mm } \backslash y\end{array}$ \\
\hline$* 28^{1}$ & 3.1 & $43.1^{1}$ & $-34^{1}$ & $1.4-1.7$ & \multirow{10}{*}{1.3} \\
\hline $45^{2}$ & 3.3 & $64^{2}$ & $-48^{2}$ & 1.4 & \\
\hline $85^{2}$ & 5.1 & $81^{3}$ & $-16^{3}$ & 1.2 & \\
\hline $120^{2}$ & 5.3 & $101^{3}$ & $-19^{4}$ & 1.4 & \\
\hline $165^{2}$ & 5.5 & $119^{4}$ & $+8.35^{4}$ & 1.3 & \\
\hline $205^{2}$ & 7.1 & $201.5^{5}$ & $-16^{4}$ & 1.3 & \\
\hline $285^{2}$ & 7.3 & $217.2^{5}$ & $-17.5^{4}$ & 1.1 & \\
\hline $345^{2}$ & 7.5 & $248.9^{5}$ & $-13^{4}$ & 1.2 & \\
\hline $415^{2}$ & 9 & $329^{6}$ & $+4^{4}$ & 1.3 & \\
\hline $520^{3}$ & 11 & $405^{6}$ & $+5^{4}$ & 1.2 & \\
\hline $680^{3}$ & 19 & $760^{6}$ & $-5^{4}$ & 0.9 & 0.9 \\
\hline
\end{tabular}

The bivalves and gastropods are sourced from infralittoral to circalittoral environments, with some mixing. Important clues come from the observation that: (i) pebbles within the deposit are covered by algal encrustations, and (ii) there is no evidence of tractive sedimentary structures. Together, those considerations appear to indicate an environment at the transition between infralittoral and circalittoral zones below the wave closure depth (estimated at ca. $-10-20 \mathrm{~m}$ below the coeval sea level).

In order to frame the studied deposit in the terrace flight in this sector of southern Calabria, we considered (Table 5): (a) the elevation of inner margin or fossil beaches associated to the terraces, (b) the age of terraces, and (c) the predicted sea level.

The inner edges of the overlying terraces have been mapped with an estimated error in elevation of $\pm 5 \mathrm{~m}[12,23]$ depending on the phenomena of erosion and/or deposition of colluvial sediments following the emergence of the terraces. Consequently, the elevations above sea level of the paleo-shorelines reported in Table 5 must be considered as the mean values. This uncertainty is, however, negligible in estimating the long-term Quaternary uplift rates involving time spans of tens to hundreds of thousands of years.

We calculated the uplift rate of distinct terraces by adding the observed elevation to the coeval eustatic position and dividing it by the age of the deposit or terrace. Table 5 shows that the uplift rates were rather constant during the Middle-Late Pleistocene.

Specifically, a lower long-term value was calculated for the MIS 19 terrace, (older than $730 \mathrm{ka}, 0.9 \mathrm{~mm} / \mathrm{y}$ ), and higher uplift rates, between 1.4 and $1.7 \mathrm{~mm} / \mathrm{y}$, were estimated for younger terraces. Uplift rates have undergone an acceleration in the Holocene (last 3-4 ka Cal BP), reaching values of $1.8-2 \mathrm{~mm} / \mathrm{y}$ along the coastline at the footwall of the Scilla Fault [86].

The uplift rate estimated for Middle-Late Pleistocene terraces supports our reconstruction of the eustatic elevation of the MIS 3.1 deposits from the Cannitello site. For this 
estimation, we used the sea level curve of Gowan et al. [101] (Figure 7) where the average between PaleoMIST 1.0 maximal $(-40 \mathrm{~m})$ and minimal $(-29 \mathrm{~m})$ of the curve at $43 \mathrm{kyrs}$ is $-34.5 \mathrm{~m}$. As mentioned before, a rigorous paleobathymetric assessment of the units under scrutiny proves problematic due to the lack of unquestionable sea level markers. Therefore, we chose a conservative approach not adopting a bathymetric correction for Cannitello 1 but an error of $-10 \mathrm{~m}$. The resulting uplift rate ranged between 1.4 and $1.7 \mathrm{~mm} / \mathrm{y}$, in agreement with the estimation from older terraces.

The uplift rate results are also consistent with our reconstruction of the MIS 3.3 eustatic sea level elevation. Indeed, they confirm that the eustatic value at $-48 \mathrm{~m}$ derived by Monaco et al. [15], based on the estimation of Waelbroeck et al. [5], may be valid.

Our numerical results and observational data confirmed that the MIS 3 RSL changes at Cannitello are governed by glacio-eustasy, whereas GIA plays a secondary role. While the $\delta^{18} \mathrm{O}$ dependent ice sheet models result in RSL curves that are always significantly lower than the observations, PaleoMIST 1.0 is the only model capable of returning a MIS 3.1 elevation that is in agreement with the observations. Indeed, we observe that there is a discrepancy (of at least 30-40 m) between the eustatic altitude of the MIS 3 of all global curves and those suggested by observations. Therefore, our results confirm previous evaluations by Pico et al. [63] and Gowan et al. [101] and support the contention that a reduction of global ice sheet volumes across the MIS 3, and specifically at the MIS 3.1 and 3.3 , is needed.

\section{Conclusions}

Estimates of the global ice volume during MIS 3 (60-29 ka) can be generally constrained between -25 and $-87 \mathrm{~m}$. Regarding the maximum altitude reached during this period, there are few observed data for a comparison between the global curves and the variations due to the different rheostatic behaviour of the mantle in coastal areas. Uncertainties of the rheostatic behaviour in the near- or far-field from the ice bulk make it difficult to estimate the local sea level during MIS 3.

Our study illustrated three new outcrops at Cannitello (southern Calabria) where we found and dated fossiliferous marine sediments deposited on uplifted metamorphic bedrock. Field evidence, appraised uplift rates of more ancient terraces, and ${ }^{14} \mathrm{C}$ age of fossil deposits sampled at an elevation of $28 \mathrm{~m}$ strongly suggest that such deposits formed during MIS 3.1.

Given the overall scarceness of MIS 3 marine outcrops that are explorable in coastal areas subject to important uplift, we consider the southern Calabrian site relevant for the assessment of past sea levels during this still poorly known interstadial.

The GIA results suggest that the $\delta^{18} \mathrm{O}$-based ice sheet models appear to significantly overestimate the ice sheet volumes during the MIS 3.1 and 3.3. Our data are in agreement with Gowan et al. [101], raising, by 40 metres, the eustatic contribution to sea level during interstadials MIS 3.1, 5.1, and 5.3 with respect to the current global sea level curve scenarios. Further, our reconstruction agrees well with the records proposing MIS 3 sea levels at depths between -18 and $-40 \mathrm{~m}$.

Author Contributions: Conceptualization, F.A., L.F., G.M., C.M., P.O., F.P., G.S. (Giovanni Scicchitano), P.S. and M.T.; methodology, P.S., L.C. and G.Q.; software, P.S. and G.S. (Giovanni Scardino); formal analysis, L.C., G.Q. and P.S.; investigation, F.A., P.O., G.S. (Giovanni Scicchitano) and F.P.; writing-original draft preparation, F.A., C.M., P.O., M.T. and F.P.; writing-review and editing, F.A., L.F., M.T., C.M., P.O., G.Q. and F.P. All authors have read and agreed to the published version of the manuscript.

Funding: This research received no external funding.

Institutional Review Board Statement: Not applicable.

Informed Consent Statement: Not applicable.

Conflicts of Interest: The authors declare no conflict of interest. 


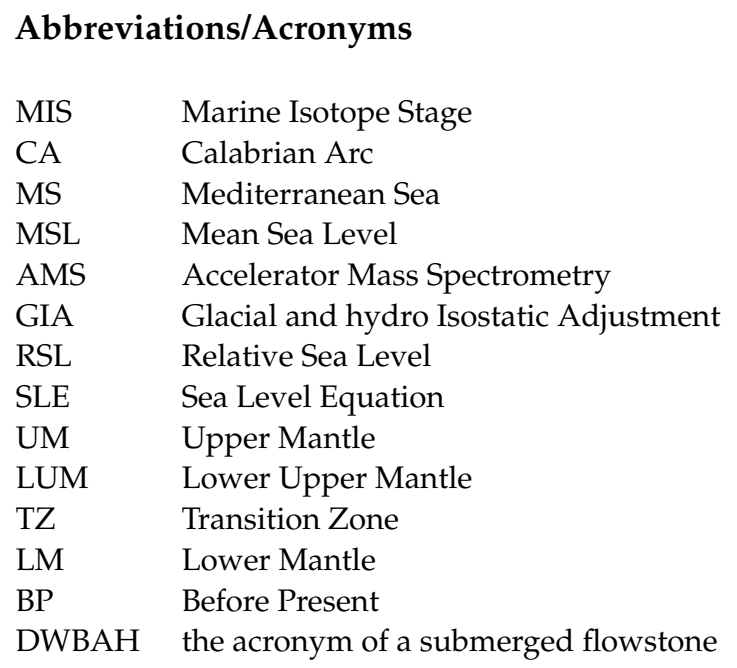

\section{References}

1. Jonkers, L.; Brummer, G.-J.A.; Peeters, F.J.C.; van Aken, H.M.; de Jong, M.F. Seasonal stratification, shell flux, and oxygen isotope dynamics of left-coiling N. pachyderma and T. quinqueloba in the western subpolar North Atlantic. Paleoceanography 2010, 25, PA2204. [CrossRef]

2. Siddall, M.; Rohling, E.J.; Thompson, W.G.; Waelbroeck, C. Marine Isotope Stage 3 Sea Level Fluctuations: Data Synthesis and New Outlook. Rev. Geophys. 2008, 46. [CrossRef]

3. Imbrie, J.; Hays, J.; Martinson, D.; McIntyre, A.; Mix, A.; Morley, J.; Pisias, N.; Prell, W.; Shackleton, N. The Orbital Theory of Pleistocene Climate: Support from a Revised Chronology of the Marine Delta 180 Record. In Milankovitch and Climate, Part 1; D. Reidel Publishing: Dordrecht, The Netherlands, 1984; pp. 269-305.

4. Rodriguez, A.; Anderson, J.; Banfield, L.; Taviani, M.; Abdulah, K.; Snow, J. Identification of a $-15 \mathrm{~m}$ Wisconsin Shoreline on the Texas Inner Continental Shelf. Palaeogeogr. Palaeoclimatol. Palaeoecol. 2000, 158, 25-43. [CrossRef]

5. Waelbroeck, C.; Labeyrie, L.; Michel, E.; Duplessy, J.C.; McManus, J.F.; Lambeck, K.; Balbon, E.; Labracherie, M. Sea-Level and Deep Water Temperature Changes Derived from Benthic Foraminifera Isotopic Records. Quat. Sci. Rev. 2002, 21, 295-305. [CrossRef]

6. Siddall, M.; Rohling, E.J.; Almogi-Labin, A.; Hemleben, C.; Meischner, D.; Schmelzer, I.; Smeed, D.A. Sea-Level Fluctuations during the Last Glacial Cycle. Nature 2003, 423, 853-858. [CrossRef] [PubMed]

7. Antonioli, F. Sea Level Change in Italy until 400 Ka: Comparing Global Sea Level Curves with Observed Data. Alp. Mediterr. Quat. 2011, 24, 11-13.

8. Lambeck, K.; Yokoyama, Y.; Purcell, T. Into and out of the Last Glacial Maximum: Sea-Level Change during Oxygen Isotope Stages 3 and 2. Quat. Sci. Rev. 2002, 21, 343-360. [CrossRef]

9. Chappell, J. Sea Level Changes Forced Ice Breakouts in the Last Glacial Cycle: New Results from Coral Terraces. Quat. Sci. Rev. 2002, 21, 1229-1240. [CrossRef]

10. Voelker, A.H.L. Global Distribution of Centennial-Scale Records for Marine Isotope Stage (MIS) 3: A Database. Quat. Sci. Rev. 2002, 21, 1185-1212. [CrossRef]

11. Kjellström, E.; Brandefelt, J.; Näslund, J.-O.; SMITH, B.; Strandberg, G.; Voelker, A.; Wohlfarth, B. Simulated Climate Conditions in Europe during the Marine Isotope Stage 3 Stadial. Boreas 2010, 39, 436-456. [CrossRef]

12. Sokołowski, R.J.; Janowski, Ł.; Hrynowiecka, A.; Molodkov, A. Evolution of Fluvial System during the Pleistocene Warm Stage (Marine Isotope Stage 7)—A Case Study from the Błądzikowo Formation, N Poland. Quat. Int. 2019, 501, 109-119. [CrossRef]

13. Zaretskaya, N.E.; Korsakova, O.P.; Panin, A.V. Marine Isotopic Stage 3 in Northeastern Europe: Geochronology and Events. Russ. Geol. Geophys. 2019, 60, 911-925. [CrossRef]

14. Peeters, J.; Busschers, F.S.; Stouthamer, E. Fluvial Evolution of the Rhine during the Last Interglacial-Glacial Cycle in the Southern North Sea Basin: A Review and Look Forward. Quat. Int. 2015, 357, 176-188. [CrossRef]

15. Monaco, C.; Barreca, G.; Stefano, A.D. Quaternary Marine Terraces and Fault Activity in the Northern Mainland Sectors of the Messina Strait (Southern Italy). Ital. J. Geosci. 2017, 136, 337-346. [CrossRef]

16. Wortel, M.J.R.; Spakman, W. Subduction and Slab Detachment in the Mediterranean-Carpathian Region. Science 2000, 290, 1910-1917. [CrossRef]

17. Piromallo, C.; Morelli, A. P Wave Tomography of the Mantle under the Alpine-Mediterranean Area. J. Geophys. Res. Solid Earth 2003, 108. [CrossRef]

18. Chiarabba, C.; De Gori, P.; Speranza, F. The Southern Tyrrhenian Subduction Zone: Deep Geometry, Magmatism and PlioPleistocene Evolution. Earth Planet. Sci. Lett. 2008, 268, 408-423. [CrossRef]

19. Scarfi, L.; Barberi, G.; Barreca, G.; Cannavò, F.; Koulakov, I.; Patanè, D. Slab Narrowing in the Central Mediterranean: The Calabro-Ionian Subduction Zone as Imaged by High Resolution Seismic Tomography. Sci. Rep. 2018, 8, 5178. [CrossRef] 
20. Carminati, E.; Doglioni, C. Europe: Mediterranean Tectonics. In Encyclopedia of Geology; Academic Press: Cambridge, MA, USA, 2004; pp. 135-146.

21. Faccenna, C.; Funiciello, F.; Civetta, L.; D'Antonio, M.; Moroni, M.; Piromallo, C. Slab Disruption, Mantle Circulation, and the Opening of the Tyrrhenian Basins. In Cenozoic Volcanism in the Mediterranean Area; GSA Special Papers; Geological Society of America: Boulder, CO, USA, 2007; Volume 418, p. 153. [CrossRef]

22. Faccenna, C.; Molin, P.; Orecchio, B.; Olivetti, V.; Bellier, O.; Funiciello, F.; Minelli, L.; Piromallo, C.; Billi, A. Topography of the Calabria Subduction Zone (Southern Italy): Clues for the Origin of Mt. Etna. Tectonics 2011, 30. [CrossRef]

23. Corradino, C.; Ganci, G.; Cappello, A.; Bilotta, G.; Calvari, S.; Del Negro, C. Recognizing Eruptions of Mount Etna through Machine Learning Using Multiperspective Infrared Images. Remote Sens. 2020, 12, 970. [CrossRef]

24. Pepe, F.; Kanari, M.; Burrato, P.; Corradino, M.; Duarte, H.; Ferranti, L.; Monaco, C.; Sacchi, M.; Tibor, G. Active Deformation Evidence in the Offshore of Western Calabria (Southern Tyrrhenian Sea) from Ultra-Resolution Multichannel Seismic Reflection Data: Results from the Gulf of Sant'Eufemia. In Proceedings of the EGU General Assembly 2020, Online, 4-8 May 2020.

25. Westaway, R. Quaternary Uplift of Southern Italy. J. Geophys. Res. Solid Earth 1993, 98, 21741-21772. [CrossRef]

26. Miyauchi, T.; Dai Pra, G.; Sylos Labini, S. Geochronology of Pleistocene Marine Terrace and Regional Tectonics in the Tyrrhenian Coast of South Calabria, Italy. Quaternario 1994, 7, 17-34.

27. Ferranti, L.; Monaco, C.; Antonioli, F.; Maschio, L.; Kershaw, S.; Verrubbi, V. The Contribution of Regional Uplift and Coseismic Slip to the Vertical Crustal Motion in the Messina Straits, Southern Italy: Evidence from Raised Late Holocene Shorelines. J. Geophys. Res. Solid Earth 2007, 112. [CrossRef]

28. Ferranti, L.; Monaco, C.; Morelli, D.; Antonioli, F.; Maschio, L. Holocene Activity of the Scilla Fault, Southern Calabria: Insights from Coastal Morphological and Structural Investigations. Tectonophysics 2008, 453, 74-93. [CrossRef]

29. Ferranti, L.; Antonioli, F.; Anzidei, M.; Monaco, C.; Stocchi, P. The Timescale and Spatial Extent of Vertical Tectonic Motions in Italy: Insights from Relative Sea-Level Changes Studies. J. Virtual Explor. 2010, 36. [CrossRef]

30. Ferranti, L.; Antonioli, F.; Monaco, C.; Scicchitano, G.; Spampinato, C.R. Uplifted Late Holocene Shorelines along the Coasts of the Calabrian Arc: Geodynamic and Seismotectonic Implications. Ital. J. Geosci. 2017, 136, 454-470. [CrossRef]

31. Roberts, G.; Meschis, M.; Houghton, S.; Underwood, C.; Briant, R. The Implications of Revised Quaternary Palaeoshoreline Chronologies for the Rates of Active Extension and Uplift in the Upper Plate of Subduction Zones. Quat. Sci. Rev. 2013, 78, 169-187. [CrossRef]

32. Pepe, F.; Bertotti, G.; Ferranti, L.; Sacchi, M.; Collura, A.; Passaro, S.; Sulli, A. Pattern and Rate of Post-20 Ka Vertical Tectonic Motion around the Capo Vaticano Promontory (W Calabria, Italy) Based on Offshore Geomorphological Indicators. Quat. Int. 2014, 332, 85-98. [CrossRef]

33. Jacques, E.; Monaco, C.; Tapponnier, P.; Tortorici, L.; Winter, T. Faulting and Earthquake Triggering during the 1783 Calabria Seismic Sequence. Geophys. J. Int. 2001, 147, 499-516. [CrossRef]

34. D'Agostino, N.; Selvaggi, G. Crustal Motion along the Eurasia-Nubia Plate Boundary in the Calabrian Arc and Sicily and Active Extension in the Messina Straits from GPS Measurements. J. Geophys. Res. Solid Earth 2004, 109. [CrossRef]

35. Palano, M.; Ferranti, L.; Monaco, C.; Mattia, M.; Aloisi, M.; Bruno, V.; Cannavò, F.; Siligato, G. GPS Velocity and Strain Fields in Sicily and Southern Calabria, Italy: Updated Geodetic Constraints on Tectonic Block Interaction in the Central Mediterranean. J. Geophys. Res. Solid Earth 2012, 117. [CrossRef]

36. Monaco, C.; Tortorici, L. Active Faulting in the Calabrian Arc and Eastern Sicily. J. Geodyn. 2000, 29, 407-424. [CrossRef]

37. Barreca, G.; Gross, F.; Scarfi, L.; Aloisi, M.; Monaco, C.; Krastel, S. The Strait of Messina: Seismotectonics and the Source of the 1908 Earthquake. Earth-Sci. Rev. 2021, 218, 103685. [CrossRef]

38. Chiarabba, C.; Jovane, L.; Di Stefano, R. A New View of Italian Seismicity Using 20 Years of Instrumental Recordings. Tectonophysics 2005, 395, 251-268. [CrossRef]

39. Tortorici, L.; Monaco, C.; Tansi, C.; Cocina, O. Recent and Active Tectonics in the Calabrian Arc (Southern Italy). Tectonophysics 1995, 243, 37-55. [CrossRef]

40. Aloisi, M.; Bruno, V.; Cannavò, F.; Ferranti, L.; Mattia, M.; Monaco, C.; Palano, M. Are the Source Models of the M 7.1 1908 Messina Straits Earthquake Reliable? Insights from a Novel Inversion and a Sensitivity Analysis of Levelling Data. Geophys. J. Int. 2013, 192, 1025-1041. [CrossRef]

41. Lombardo, G. Studio Stratigrafico Del Plio-Pleistocene Del Bacino Di Reggio Calabria. Atti Acc. Gioenia Sci. Nat. Catania 1980, 12, 233-298.

42. Barrier, P. Evolution Paléogéographique du Détroit de Messine au Pliocéne et au Pléistocène. G. Geol. 1996, 3, 7-24.

43. Monaco, C.; Tortorici, L.; Nicolich, R.; Cernobori, L.; Costa, M. From Collisional to Rifted Basins: An Example from the Southern Calabrian Arc (Italy). Tectonophysics 1996, 266, 233-249. [CrossRef]

44. Dumas, B.; Gueremy, P.; Lhenaf, R.; Raffy, J. Reliéf et Néotectonique de La Facade Orientale Du Détroit de Messine (Calabre, Italie). Travaux RCP 1978, 461, 105-125.

45. Dumas, B.; Gueremy, P.; Lhenaf, R.; Raffy, J. Rates of Uplift as Shown by Raised Quaternary Shorelines in Southern Calabria (Italy). Z. Geomorphol. 1987, 63, 119-132.

46. Ghisetti, F. Upper Pliocene-Pleistocene Uplift Rates as Indicators of Neotectonic Pattern: An Example from Southern Calabria (Italy). Z. Geomorphol. Suppl. 1981, 40, 93-118. 
47. Ghisetti, F. L'evoluzione Strutturale Del Bacino Plio-Pleistocenico Di Reggio Calabria Nel Quadro Geodinamico Dell'Arco Calabro. Boll. Geol. Ital. 1981, 100, 433-466.

48. Ghisetti, F. Fault Parameters in the Messina Strait (Southern Italy) and Relations with the Seismogenic Source. Tectonophysics 1992, 210, 117-133. [CrossRef]

49. Pirrotta, C.; Barbano, M.; Monaco, C. Evidence of Active Tectonics in Southern Calabria (Italy) by Geomorphic Analysis: The Examples of the Catona and Petrace Rivers. Ital. J. Geosci. 2016, 135, 142-156. [CrossRef]

50. Balescu, S.; Dumas, B.; Guérémy, P.; Lamothe, M.; Lhénaff, R.; Raffy, J. Thermoluminescence Dating Tests of Pleistocene Sediments from Uplifted Marine Shorelines along the Southwest Coastline of the Calabrian Peninsula (Southern Italy). Palaeogeogr. Palaeoclimatol. Palaeoecol. 1997, 130, 25-41. [CrossRef]

51. Chappell, J.; Shackleton, N.J. Oxygen Isotopes and Sea Level. Nature 1986, 324, 137-140. [CrossRef]

52. Bonifiglio, L. Il Tirreniano Di Bovetto e Ravagnese Presso Reggio Calabria. Quaternaria 1972, 16, $137-148$.

53. Dumas, B.; Raffy, J. Late Pleistocene Tectonic Activity Deduced from Uplifted Marine Terraces in Calabria, Facing the Strait of Messina. Quat. Nova 2004, 8, 79-99.

54. Ruggieri, G.; Sprovieri, R. La Definizione Dello Strtotipo Del Piano Siciliano e Le Sue Conseguenze. Nat. Sicil. 1975, IV, 187-214.

55. Benjamin, J.; Rovere, A.; Fontana, A.; Furlani, S.; Vacchi, M.; Inglis, R.H.; Galili, E.; Antonioli, F.; Sivan, D.; Miko, S.; et al. Late Quaternary Sea-Level Changes and Early Human Societies in the Central and Eastern Mediterranean Basin: An Interdisciplinary Review. Quat. Int. 2017, 449, 29-57. [CrossRef]

56. Richards, D.A.; Smart, P.L.; Edwards, R.L. Maximum Sea Levels for the Last Glacial Period from U-Series Ages of Submerged Speleothems. Nature 1994, 367, 357-360. [CrossRef]

57. Li, W.-X.; Lundberg, J.; Dickin, A.P.; Ford, D.C.; Schwarcz, H.P.; McNutt, R.; Williams, D. High-Precision Mass-Spectrometric Uranium-Series Dating of Cave Deposits and Implications for Palaeoclimate Studies. Nature 1989, 339, 534-536. [CrossRef]

58. Lundberg, J.; Ford, D.C. Late Pleistocene Sea Level Change in the Bahamas from Mass Spectrometric U-Series Dating of Submerged Speleothem. Quat. Sci. Rev. 1994, 13, 1-14. [CrossRef]

59. Antonioli, F.; Furlani, S.; Montagna, P.; Stocchi, P. The Use of Submerged Speleothems for Sea Level Studies in the Mediterranean Sea: A New Perspective Using Glacial Isostatic Adjustment (GIA). Geosciences 2021, 11, 77. [CrossRef]

60. Berkman, P.A.; Andrews, J.T.; Björck, S.; Colhoun, E.A.; Emslie, S.D.; Goodwin, I.D.; Hall, B.L.; Hart, C.P.; Hirakawa, K.; Igarashi, A.; et al. Circum-Antarctic Coastal Environmental Shifts during the Late Quaternary Reflected by Emerged Marine Deposits. Antarct. Sci. 1998, 10, 345-362. [CrossRef]

61. Taviani, M.; Anderson, J. Response of Biogenic Carbonate Factories to Ice Sheet and Ice Shelf Dynamics: A Largely Deglaciated Ross Sea since Isotope Stage 3? In Proceedings of the 7th International Symposium on Antarctic Earth Sciences, Siena, Italy, 10-15 September 1995; p. 367.

62. Anderson, J.B.; Shipp, S.S. Evolution of the West Antarctic Ice Sheet. In The West Antarctic Ice Sheet: Behavior and Environments; Antarctic Research Series; Alley, R., Bindschadler, R., Eds.; American Geophysical Union: Washington, DC, USA, 2001; Volume 77, pp. $45-57$.

63. Pico, T.; Mitrovica, J.; Ferrier, K.; Braun, J. Global Ice Volume during MIS 3 Inferred from a Sea-Level Analysis of Sedimentary Core Records in the Yellow River Delta. Quat. Sci. Rev. 2016, 152, 72-79. [CrossRef]

64. Pasini, G.; Colalongo, M.; Curzi, P.; Taviani, M. Analisi Paleoecologica Degli Ambienti Tardo-Quaternari Del Dosso Gallignani (Adriatico Centro-Meridionale) Mediante Lo Studio Paleontologico Di Carote. Boll. Soc. Paleontol. Ital. 1993, 32, 113-130.

65. Jouet, G.; Berne, S.; Rabineau, M.; Bassetti, M.-A.; Bernier, P.; Dennielou, B.; Sierro, F.J.; Flores, J.A.; Taviani, M. Shoreface Migrations at the Shelf Edge and Sea-Level Changes around the Last Glacial Maximum (Gulf of Lions, NW Mediterranean). Mar. Geol. 2006, 234, 21-42. [CrossRef]

66. Maselli, V.; Trincardi, F.; Asioli, A.; Ceregato, A.; Rizzetto, F.; Taviani, M. Delta Growth and River Valleys: The Influence of Climate and Sea Level Changes on the South Adriatic Shelf (Mediterranean Sea). Quat. Sci. Rev. 2014, 99, 146-163. [CrossRef]

67. Kirc1-Elmas, E.; Nazik, N.; Kapan, S.; Meric, E.; Zor, E.S.; Kalkan, B.; Dogan, T.; Guney, A. Ponto-Caspian and Mediterranean Faunal and Floral Records of Upper Pleistocene-Holocene Sediments from the İzmit Gulf (Marmara Sea, Turkey). Acta Palaeontol. Rom. 2021, 17, 23-62. [CrossRef]

68. Amorosi, A.; Colalongo, M.L.; Fusco, F.; Pasini, G.; Fiorini, F. Glacio-Eustatic Control of Continental-Shallow Marine Cyclicity from Late Quaternary Deposits of the Southeastern Po Plain, Northern Italy. Quat. Res. 1999, 52, 1-13. [CrossRef]

69. Amorosi, A.; Colalongo, M.L.; Fiorini, F.; Fusco, F.; Pasini, G.; Vaiani, S.C.; Sarti, G. Palaeogeographic and Palaeoclimatic Evolution of the Po Plain from 150-Ky Core Records. Glob. Planet. Chang. 2004, 40, 55-78. [CrossRef]

70. Bassetti, M.A.; Berné, S.; Jouet, G.; Taviani, M.; Dennielou, B.; Flores, J.-A.; Gaillot, A.; Gelfort, R.; Lafuerza, S.; Sultan, N. The 100-Ka and Rapid Sea Level Changes Recorded by Prograding Shelf Sand Bodies in the Gulf of Lions (Western Mediterranean Sea). Geochem. Geophys. Geosystems 2008, 9. [CrossRef]

71. Piva, A.; Asioli, A.; Schneider, R.R.; Trincardi, F.; Andersen, N.; Colmenero-Hidalgo, E.; Dennielou, B.; Flores, J.-A.; Vigliotti, L. Climatic Cycles as Expressed in Sediments of the PROMESS1 Borehole PRAD1-2, Central Adriatic, for the Last 370 Ka: 1. Integrated Stratigraphy. Geochem. Geophys. Geosystems 2008, 9. [CrossRef]

72. Maselli, V.; Trincardi, F.; Cattaneo, A.; Ridente, D.; Asioli, A. Subsidence Pattern in the Central Adriatic and Its Influence on Sediment Architecture during the Last 400 Kyr. J. Geophys. Res. Solid Earth 2010, 115. [CrossRef] 
73. Kuhlmann, J.; Asioli, A.; Trincardi, F.; Klügel, A.; Huhn, K. Sedimentary Response to Milankovitch-Type Climatic Oscillations and Formation of Sediment Undulations: Evidence from a Shallow-Shelf Setting at Gela Basin on the Sicilian Continental Margin. Quat. Sci. Rev. 2015, 108, 76-94. [CrossRef]

74. Matthews, I.P.; Trincardi, F.; Lowe, J.J.; Bourne, A.J.; MacLeod, A.; Abbott, P.M.; Andersen, N.; Asioli, A.; Blockley, S.P.E.; Lane, C.S.; et al. Developing a Robust Tephrochronological Framework for Late Quaternary Marine Records in the Southern Adriatic Sea: New Data from Core Station SA03-11. Quat. Sci. Rev. 2015, 118, 84-104. [CrossRef]

75. Pellegrini, C.; Asioli, A.; Bohacs, K.M.; Drexler, T.M.; Feldman, H.R.; Sweet, M.L.; Maselli, V.; Rovere, M.; Gamberi, F.; Valle, G.D.; et al. The Late Pleistocene Po River Lowstand Wedge in the Adriatic Sea: Controls on Architecture Variability and Sediment Partitioning. Mar. Pet. Geol. 2018, 96, 16-50. [CrossRef]

76. Campo, B.; Bruno, L.; Amorosi, A. Basin-Scale Stratigraphic Correlation of Late Pleistocene-Holocene (MIS 5e-MIS 1) Strata across the Rapidly Subsiding Po Basin (Northern Italy). Quat. Sci. Rev. 2020, 237, 106300. [CrossRef]

77. Antonioli, F.; Ferranti, L. Evidenze Geomorfologiche Sommerse Nelle Aree Costiere Italiane Di Uno Stazionamento Del Livello Del Mare Ubicato a circa-20 m e Attribuito Allo Stadio 3. Quaternario 1996, 9, 205-208.

78. Taviani, M. The Stage 3 Sea-Level HighsStand and Its Potential Implications on the Decoupling of Antarctic Ice Sheets. Terra Antart. Rep. 2003, 8, 159-161.

79. Doğan, U.; Koçyiğit, A.; Varol, B.; Özer, İ.; Molodkov, A.; Zöhra, E. MIS 5a and MIS 3 Relatively High Sea-Level Stands on the Hatay-Samandağ Coast, Eastern Mediterranean, Turkey. Quat. Int. 2012, 262, 65-79. [CrossRef]

80. Brunović, D.; Miko, S.; Hasan, O.; Papatheodorou, G.; Ilijanić, N.; Miserocchi, S.; Correggiari, A.; Geraga, M. Late Pleistocene and Holocene Paleoenvironmental Reconstruction of a Drowned Karst Isolation Basin (Lošinj Channel, NE Adriatic Sea). Palaeogeogr. Palaeoclimatol. Palaeoecol. 2020, 544, 109587. [CrossRef]

81. Surić, M.; Juračić, M.; Horvatinčić, N.; Bronić, I.K. Late Pleistocene-Holocene Sea-Level Rise and the Pattern of Coastal Karst Inundation: Records from Submerged Speleothems along the Eastern Adriatic Coast (Croatia). Mar. Geol. 2005, 214, 163-175. [CrossRef]

82. Bard, E.; Antonioli, F.; Silenzi, S. Sea-Level during the Penultimate Interglacial Period Based on a Submerged Stalagmite from Argentarola Cave (Italy). Earth Planet. Sci. Lett. 2002, 196, 135-146. [CrossRef]

83. Dutton, A.; Bard, E.; Antonioli, F.; Esat, T.M.; Lambeck, K.; McCulloch, M.T. Phasing and Amplitude of Sea-Level and Climate Change during the Penultimate Interglacial. Nat. Geosci. 2009, 2, 355-359. [CrossRef]

84. Dutton, A.; Scicchitano, G.; Monaco, C.; Desmarchelier, J.M.; Antonioli, F.; Lambeck, K.; Esat, T.M.; Fifield, L.K.; McCulloch, M.T.; Mortimer, G. Uplift Rates Defined by U-Series and 14C Ages of Serpulid-Encrusted Speleothems from Submerged Caves near Siracusa, Sicily (Italy). Quat. Geochronol. 2009, 4, 2-10. [CrossRef]

85. Scicchitano, G.; Monaco, C. Karstic Caves and Submerged Paleo-Shorelines in the Coastal Area between Capo Santa Panagia and Ognina (Siracusa, South-Eastern Sicily). Alp. Mediterr. Quat. 2006, 19, 187-194.

86. Ferranti, L.; Santoro, E.; Mazzella, M.E.; Monaco, C.; Morelli, D. Active Transpression in the Northern Calabria Apennines, Southern Italy. Tectonophysics 2009, 476, 226-251. [CrossRef]

87. Santoro, E.; Mazzella, M.E.; Ferranti, L.; Randisi, A.; Napolitano, E.; Rittner, S.; Radtke, U. Raised Coastal Terraces along the Ionian Sea Coast of Northern Calabria, Italy, Suggest Space and Time Variability of Tectonic Uplift Rates. Quat. Int. 2009, 206, 78-101. [CrossRef]

88. Santoro, E.; Ferranti, L.; Burrato, P.; Mazzella, M.E.; Monaco, C. Deformed Pleistocene Marine Terraces along the Ionian Sea Margin of Southern Italy: Unveiling Blind Fault-Related Folds Contribution to Coastal Uplift. Tectonics 2013, 32, 737-762. [CrossRef]

89. Zander, A.; Fulling, A.; Brückner, H.; Mastronuzzi, G. OSL Dating of Upper Pleistocene Littoral Sediments: A Contribution to the Chronostratigraphy of Raised Marine Terraces Bordering the Gulf of Taranto, South Italy. Geogr. Fis. Din. Quat. 2006, 29 , 33-50.

90. Sauer, D.; Wagner, S.; Brückner, H.; Scarciglia, F.; Mastronuzzi, G.; Stahr, K. Soil Development on Marine Terraces near Metaponto (Gulf of Taranto, Southern Italy). Quat. Int. 2010, 222, 48-63. [CrossRef]

91. Taviani, M.; Angeletti, L.; Cardone, F.; Montagna, P.; Danovaro, R. A Unique and Threatened Deep Water Coral-Bivalve Biotope New to the Mediterranean Sea Offshore the Naples Megalopolis. Sci. Rep. 2019, 9, 3411. [CrossRef] [PubMed]

92. Calcagnile, L.; Maruccio, L.; Scrimieri, L.; delle Side, D.; Braione, E.; D’Elia, M.; Quarta, G. Development and Application of Facilities at the Centre for Applied Physics, Dating and Diagnostics (CEDAD) at the University of Salento during the Last 15 years. Nucl. Instrum. Methods Phys. Res. Sect. B Beam Interact. Mater. At. 2019, 456, 252-256. [CrossRef]

93. Heaton, T.J.; Köhler, P.; Butzin, M.; Bard, E.; Reimer, R.W.; Austin, W.E.N.; Ramsey, C.B.; Grootes, P.M.; Hughen, K.A.; Kromer, B.; et al. Marine20-The Marine Radiocarbon Age Calibration Curve (0-55,000 Cal BP). Radiocarbon 2020, 62, 779-820. [CrossRef]

94. Siani, G.; Paterne, M.; Arnold, M.; Bard, E.; Métivier, B.; Tisnerat, N.; Bassinot, F. Radiocarbon Reservoir Ages in the Mediterranean Sea and Black Sea. Radiocarbon 2000, 42, 271-280. [CrossRef]

95. Peltier, W.R. GLOBAL GLACIAL ISOSTASY AND THE SURFACE OF THE ICE-AGE EARTH: The ICE-5G (VM2) Model and GRACE. Annu. Rev. Earth Planet. Sci. 2004, 32, 111-149. [CrossRef]

96. Stocchi, P.; Spada, G. Influence of Glacial Isostatic Adjustment upon Current Sea Level Variations in the Mediterranean. Tectonophysics 2009, 474, 56-68. [CrossRef]

97. Lisiecki, L.E.; Raymo, M.E. A Pliocene-Pleistocene Stack of 57 Globally Distributed Benthic $\Delta 180$ Records. Paleoceanography 2005, 20. [CrossRef] 
98. Argus, D.F.; Peltier, W.R.; Drummond, R.; Moore, A.W. The Antarctica Component of Postglacial Rebound Model ICE-6G_C (VM5a) Based on GPS Positioning, Exposure Age Dating of Ice Thicknesses, and Relative Sea Level Histories. Geophys. J. Int. 2014, 198, 537-563. [CrossRef]

99. de Boer, B.; Stocchi, P.; Whitehouse, P.L.; van de Wal, R.S.W. Current State and Future Perspectives on Coupled Ice-Sheet-SeaLevel Modelling. Quat. Sci. Rev. 2017, 169, 13-28. [CrossRef]

100. de Boer, B.; Stocchi, P.; van de Wal, R.S.W. A Fully Coupled 3-D Ice-Sheet-Sea-Level Model: Algorithm and Applications. Geosci. Model Dev. 2014, 7, 2141-2156. [CrossRef]

101. Gowan, E.J.; Zhang, X.; Khosravi, S.; Rovere, A.; Stocchi, P.; Hughes, A.L.C.; Gyllencreutz, R.; Mangerud, J.; Svendsen, J.-I.; Lohmann, G. A New Global Ice Sheet Reconstruction for the Past 80000 Years. Nat. Commun. 2021, 12, 1199. [CrossRef] [PubMed]

102. Antonioli, F.; Furlani, S.; Montagna, P.; Stocchi, P.; Calcagnile, L.; Quarta, G.; Cecchinel, J.; Presti, V.L.; Morticelli, M.G.; Martin, F.F.; et al. Submerged Speleothems and Sea Level Reconstructions: A Global Overview and New Results from the Mediterranean Sea. Water 2021, 13, 1663. [CrossRef]

103. Antonioli, F.; Ferranti, L.; Stocchi, P.; Deiana, G.; Lo Presti, V.; Furlani, S.; Marino, C.; Orru, P.; Scicchitano, G.; Trainito, E.; et al. Morphometry and Elevation of the Last Interglacial Tidal Notches in Tectonically Stable Coasts of the Mediterranean Sea. Earth-Sci. Rev. 2018, 185, 600-623. [CrossRef] 